\title{
The Recent foraminifera and facies of the Bass Canyon: a temperate submarine canyon in Gippsland, Australia
}

\author{
ANDREW J. SMITH \& STEPHEN J. GALLAGHER \\ School of Earth Sciences, The University of Melbourne, Victoria 3010, Australia (e-mail: sjgall@unimelb.edu.au)
}

\begin{abstract}
This study describes the foraminifera and facies of a large submarine canyon: the Bass Canyon, in the Gippsland Basin off the coast of southeastern Australia. The study incorporates facies analyses and interpretations of three types of foraminiferal distributional data: forms alive at time of collection, recently dead forms and relict forms. Four principle biofacies types occur: (1) middle shelf to shelf-break carbonate sand; (2) oxic upper to middle bathyal carbonate sand and gravel, with abundant bryozoans; (3) reduced oxic middle bathyal carbonate sand and gravel and (4) lower bathyal oxic muddy sand to Globigerina Ooze.

Correspondence Analysis of the 61 parameters (percentage abundance of foraminifera and \% carbonate) in 36 samples yielded a clear depth-related pattern, although other related parameters such as dissolved oxygen and substrate also exert control on the foraminiferal assemblages.

Relict foraminifera are restricted to shelfal depths, shallower than $145 \mathrm{~m}$. This pattern is similar to other shelf regions in Australia, where shelf areas were exposed during the Last Glacial Maximum, reworking shelf facies shallower than $150 \mathrm{~m}$. The distribution of living foraminifera is similar to the distribution of the total assemblage, suggesting that the region has not been significantly mixed by wave, slump or bioturbation processes.

The majority of the modern Bass Canyon foraminiferal assemblages are cosmopolitan species, with few (semi-)endemic taxa that are mostly restricted to the shelf. These modern deeper-living forms are more conservative since they evolved in relatively lower stress eutrophic environments than their shallower oligotrophic dwelling contemporaries.

The foraminiferal and facies analogues of this study on the Bass Canyon may be used as a modern palaeoenvironmental analyses of the Gippsland and Otway Neogene sedimentary deep-sea successions. This will lead ultimately to a better understanding of the evolution of the basins in southeastern Australia, in an area influenced by the Southern Ocean during the Cenozoic. J. Micropalaeontol. 22(1): 63-83, July 2003.
\end{abstract}

\section{INTRODUCTION}

The Bass Canyon is an east-south-east trending submarine canyon, located in the Gippsland Basin off the coast of southeast Australia (Fig. 1). It is at the confluence of several smaller canyons from the continental shelf and is approximately $10 \mathrm{~km}$ wide and $80 \mathrm{~km}$ long and extends in an approximate straight line. At $4000 \mathrm{~m}$ water depth, the Bass Canyon exits the continental slope and passes onto the abyssal plain, terminating as the Bass Fan.

Summaries of modern marine sediment distribution patterns have been completed in the region by Jones \& Davies (1983) and Smith et al. (2001), although there have been no previous detailed studies on the foraminiferal biofacies of the Bass Canyon. The modern foraminiferal distributions are better known in other parts of Australia and New Zealand, and have concentrated on the temperate shelf to marginal marine regions, and have been used as analogues for palaeoenvironmental interpretation of the neritic, Cenozoic, cool water carbonate successions of the Otway and Gippsland Basin (Parr, 1945; Collins, 1953, 1973; Albani, 1968; Johnson \& Albani, 1973; Apthorpe, 1980; Cann \& Gostin, 1985; Cann et al., 1988; Gallagher \& Holdgate, 1996, 2000; Li et al., 1996a, b, 1999; Holdgate \& Gallagher, 1997; Hayward et al., 1999; Gallagher et al., 1999, 2001).

It is intended that the foraminiferal and facies analogues of this study on the Bass Canyon will greatly improve palaeo- environmental analyses of the deep sea carbonate facies of the Gippsland and Otway Tertiary sedimentary successions.

\section{METHODS}

The Bass Canyon samples in this study were collected from 18 September to 5 October 1998 on the R/V Franklin from three different transects (C, D, E, on Fig. 1). The samples were obtained using a Smith/McIntyre grab, which yields approximately $0.1 \mathrm{~m}^{3}$ of undisturbed seabed sediment.

Upon collection, the samples were preserved in an ethanol/ Rose Bengal solution. The Rose Bengal stains the protoplasm of living foraminifera, providing valuable information about the live/dead ratios within different assemblages (Murray, 1991). Subsequently, these samples were washed in a water/Rose Bengal solution following the technique outlined in Walton (1952). Foraminifers interpreted to have been alive at the time of collection showed consistent staining of the protoplasm within their final chamber/s. Foraminifera were interpreted to be relict or fossil forms if they showed evidence of alteration due to diagenesis or weathering. Most relict forms were found to have been ferruginized, with a limonite staining.

Once samples were dried, over 300 foraminifera were 'nonselectively' picked from each of the 36 samples. This ensures that those picked are statistically representative of the entire assemblage. Fifteen species of planktonic and 205 species of benthic foraminifera were identified in the 12,000 foraminifera collected. 


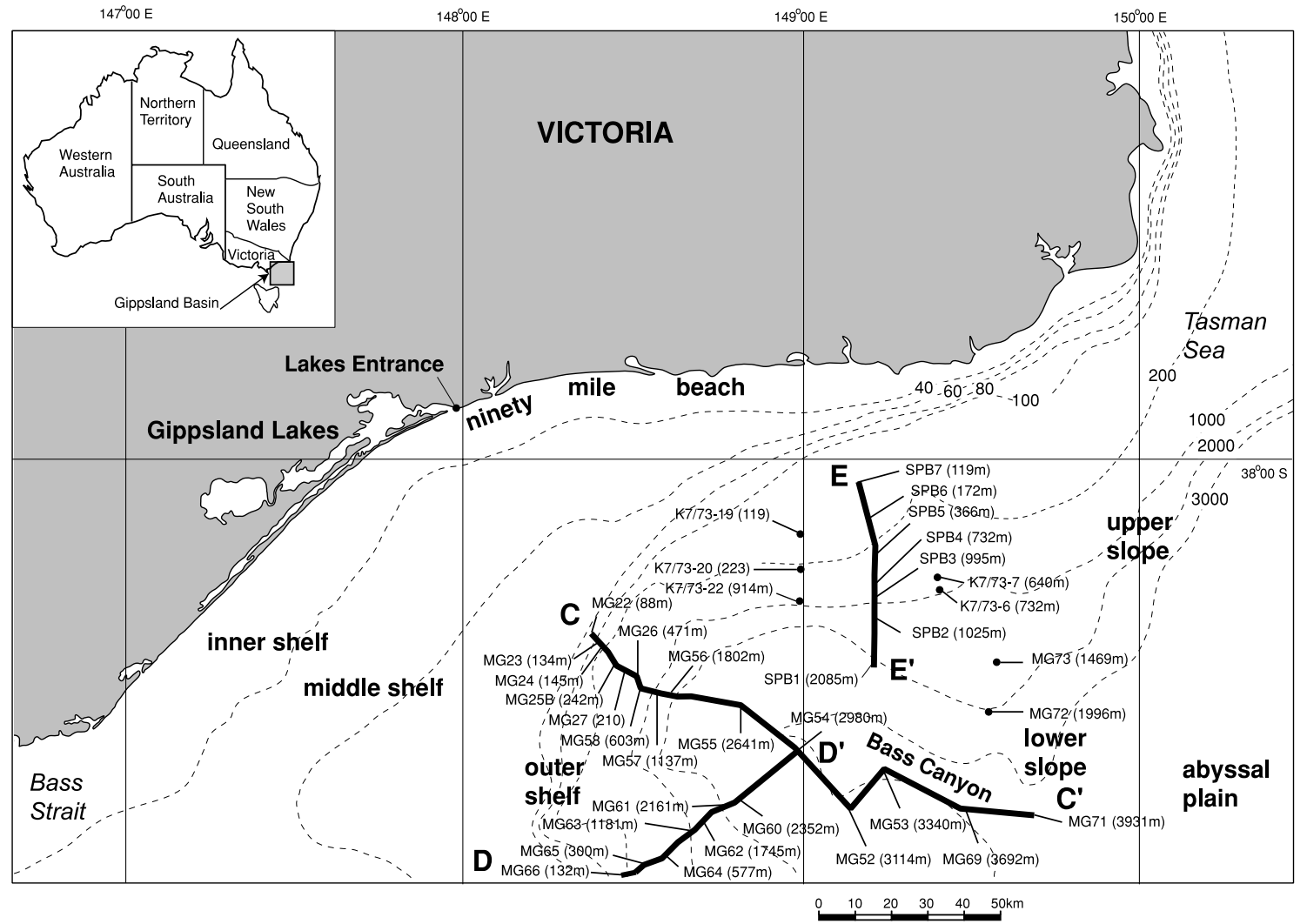

Fig. 1. Location of the Bass Canyon samples and transects discussed in this study.

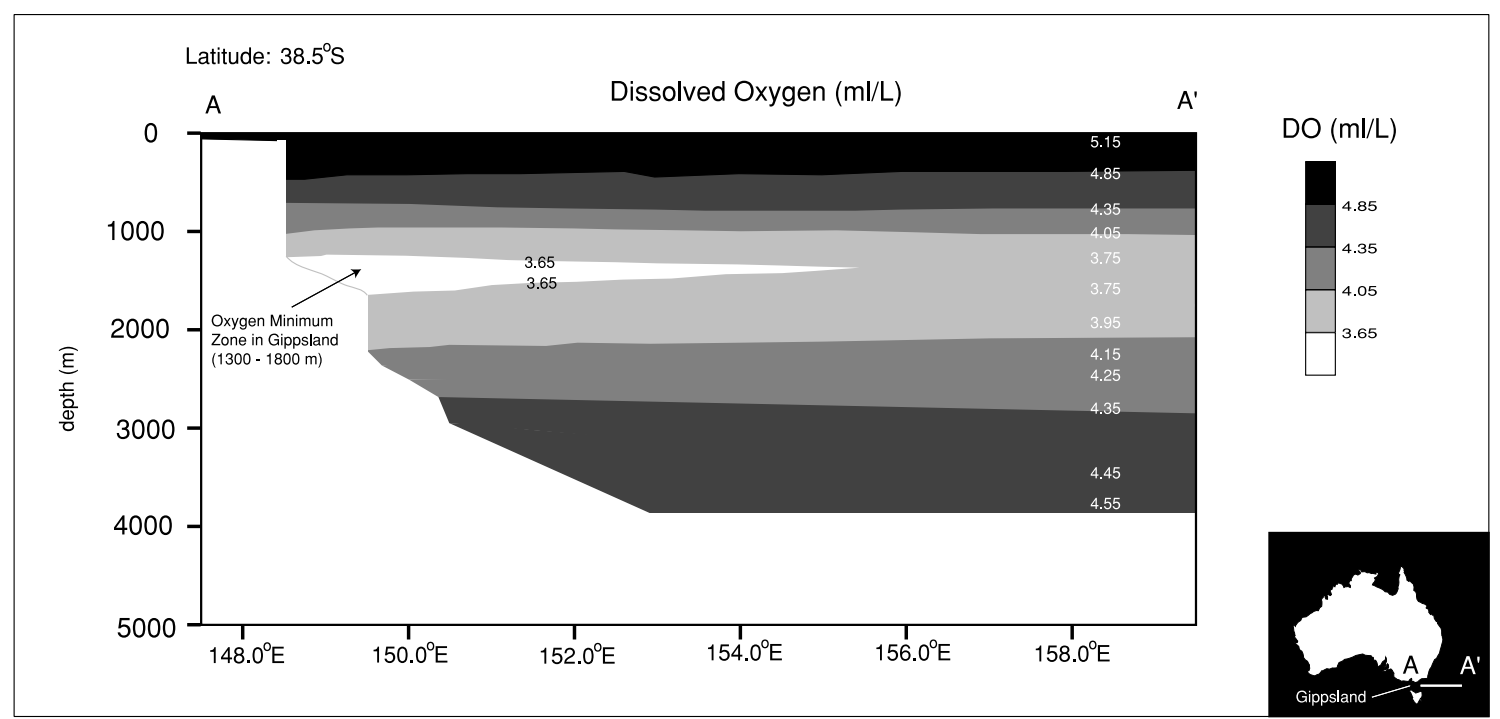

Fig. 2. The dissolved oxygen profile in the Bass Canyon along latitude $38.5^{\circ} \mathrm{S}$.

Three types of distributional data were collected for the foraminiferal assemblage in each sample: forms interpreted to have been alive at time of collection (=live forms) with Rose Bengal solution; forms with no evident protoplasm at time of collection nor any visible diagenetic alteration (=recently dead forms) and relict forms (Smith et al., 2001).
For descriptive purposes the fauna and facies of the Bass Canyon will be described in terms of the four dominant faunal types, shelfal, upper to middle bathyal (oxic), bathyal (reduced oxic) and middle to lower bathyal (oxic). The reduced oxic samples are those that occur within the Oxygen Minimum Zone (see Fig. 2) and contain characteristic foraminifera of reduced 
oxygen conditions, such as Rhabdammina and Uvigerina (Sen Gupta \& Machain-Castillo, 1993).

The shelfal samples include: five samples from the northeast section of the area of study from depths between $88 \mathrm{~m}$ to $242 \mathrm{~m}$ (transect C) at the top of the Bass Canyon; two from the south-east section of the area from depths of $132 \mathrm{~m}$ to $300 \mathrm{~m}$ (transect D) at the top of a smaller feeder canyon of the Bass Canyon; and four samples from the northern section of the area of study immediately above the steeply dipping canyon wall (transect E and adjacent samples) (see Fig. 1).

The upper-middle bathyal (oxic) samples include: three samples from transect $\mathrm{C}$; one from transect $\mathrm{D}$; and five from transect $\mathrm{E}$ (along with adjacent samples), from depths between 366 and $1137 \mathrm{~m}$.

The nine bathyal (reduced oxic) samples studied come from depths between 995 and $2980 \mathrm{~m}$. This zone is classified as 'reduced oxic' due to the high percentage of Rhabdammina spp. and Bulimina marginata. This zone also corresponds with the oxygen minimum zone of the data from Levitus (1982) (Fig. 2).

The seven middle to lower bathyal (oxic) samples come from depths between 1025 and $3931 \mathrm{~m}$, and it is suggested increased dissolved oxygen conditions exist compared to the 'reduced oxic' samples described earlier due to a decrease in abundance of the reduced oxygen indicators, such as Rhabdammina spp. and Bulimina spp. The Levitus (1982) data also show an increase in dissolved oxygen in the region at depths greater than $2000 \mathrm{~m}$ (Fig. 2).

In additional to the samples collected aboard the $\mathrm{R} / \mathrm{V}$ Franklin, samples collected by David Taylor in 1968 (the 'SPB' samples), and samples taken aboard the Kimbla in 1973 (the 'K7/73' samples) have been used to supplement the results.

Percentages of $\mathrm{CaCO}_{3}$ were calculated for each sample by dissolving approximately $0.3 \mathrm{~g}$ of the crushed sample using $50 \%$ $\mathrm{HCl}$ and measuring the amount of $\mathrm{CO}_{2}$ gas released (Carver, 1971). Facies analysis was completed by analyses of the dried unprocessed sample, which was split and then viewed under a reflected light microscope.

\section{REGIONAL OCEANOGRAPHIC SETTING}

The Gippsland Basin covers 56,000 km² (Smith, 1982), of which two-thirds is offshore, and lies between $38^{\circ} \mathrm{S}$ and $41^{\circ} \mathrm{S}$ off the coast of southeast Australia (see Fig. 1). The curved morphology of its tapering shelf break is principally determined by the occurrence of a large submarine canyon that reaches a maximum depth of $4000 \mathrm{~m}$ (the Bass Canyon). Most of the basin lies in Bass Strait, a shallow sea between mainland Australia and Tasmania in the west, and the Tasman Sea in the east. The slope of the Gippsland shelf ranges from $0.06^{\circ}$ in the inner to middle shelf $(0-100 \mathrm{~m})$ to $0.3^{\circ}$ in the outer shelf $(100-200 \mathrm{~m})$. Slopes up to $6^{\circ}$ occur at the shelf break at the head of the Bass Canyon (deeper than $200 \mathrm{~m}$ ), it decreases to $0.6^{\circ}$ approaching the bottom of the Bass Canyon in depths of $\sim 3500 \mathrm{~m}$.

The Gippsland region (Fig. 3) lies $500 \mathrm{~km}$ north of the Subtropical Convergence (STC) ocean front, which occurs around $45^{\circ} \mathrm{S}$, and marks the boundary between the subantarctic and temperate oceanic regions. The STC is identified by the summer $15^{\circ} \mathrm{C}$ isotherm and winter $10^{\circ} \mathrm{C}$ isotherm outcropping on the surface (Martinez, 1994). The contact between the

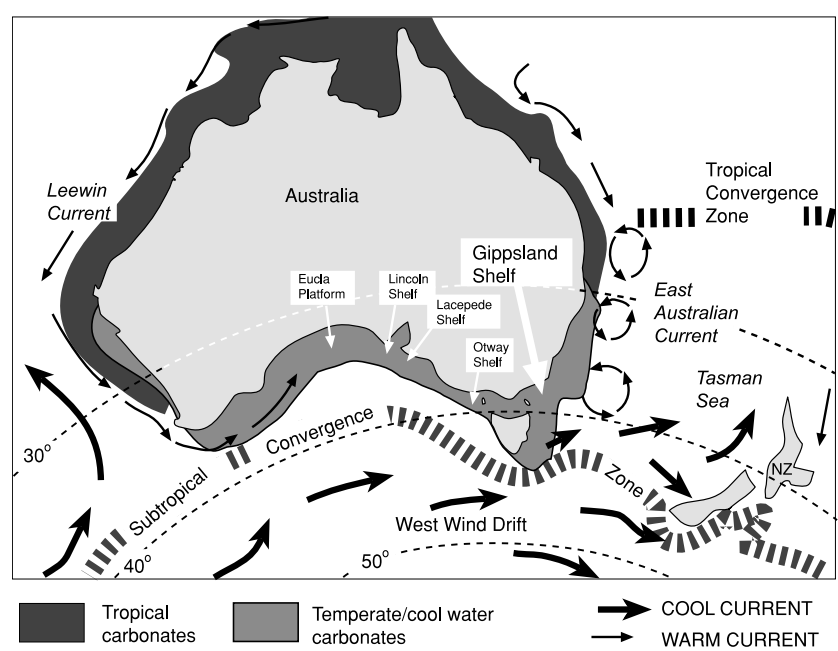

Fig. 3. The oceanographic setting of the Gippsland area and shelfal areas of southern Australia, adapted from Martinez (1994) and James et al. (1999).

temperate Tasman Current and the subtropical East Australian Current, lies at about $30^{\circ} \mathrm{S}$, and is known as the Subtropical Divergence (Martinez, 1994).

The unstable, predominantly wind-driven East Australian Current (EAC) is the western boundary current of the South West Pacific (Hamon, 1965; Tomczak \& Godfrey, 1994). Between $27^{\circ} \mathrm{S}$ and $32^{\circ} \mathrm{S}$ the current flows southward along the shelf break. South of $32^{\circ} \mathrm{S}$ however, the current forms numerous anticyclonic eddies (Hamon, 1965; Davies, 1979).

During winter a dense cold saline water mass $(35.7 \%$ ) leaves the Bass Strait and travels northward along the shelf and sinks at the head of the Bass Canyon. Part of this water mass also travels east across the shelf and sinks into the Tasman Sea just beyond the position of the shelf break between 300 and $400 \mathrm{~m}$ (Godfrey et al., 1980; Tomczak, 1985). This is the "Bass Strait Cascade", which is a density current that travels at speeds of up to $0.5 \mathrm{~m} / \mathrm{sec}$ below $200 \mathrm{~m}$. It is, therefore, an important local control on the facies at the shelf break at the head of the Bass Canyon.

Mean sea surface temperatures for offshore Gippsland vary from $12^{\circ} \mathrm{C}$ to $16^{\circ} \mathrm{C}$ in winter and $18^{\circ} \mathrm{C}$ to $20^{\circ} \mathrm{C}$ in summer (Levitus, 1982), thus it is a temperate or cool-water region (sensu James, 1997). The $15^{\circ} \mathrm{C}$ thermocline is at a depth of around $100 \mathrm{~m}$ and the $10^{\circ} \mathrm{C}$ thermocline is at $400 \mathrm{~m}$, where seasonal changes in temperature occur deeper than $200 \mathrm{~m}$ depth (Knauss, 1997).

Mean annual salinities across the Gippsland shelf are stenohaline and range from $35.2 \%$ at $200 \mathrm{~m}$ depth to $35.5 \%$ at $50 \mathrm{~m}$ (Levitus, 1982).

Data from Levitus (1982), as shown in Figure 2, records an oxygen minimum zone of oxic condition $(3.65 \mathrm{ml} / \mathrm{l})$ near the seabed between 1300 and $1800 \mathrm{~m}$ water depth on the west side of the $38.5^{\circ} \mathrm{S}$ latitude. Dissolved oxygen increases below this depth in the deeper water of the east.

\section{REGIONAL SEDIMENTOLOGICAL SETTING}

Southeastern Australia is a typical cool-water carbonate depositional realm. Figure 4 shows a contour map of percentage of 


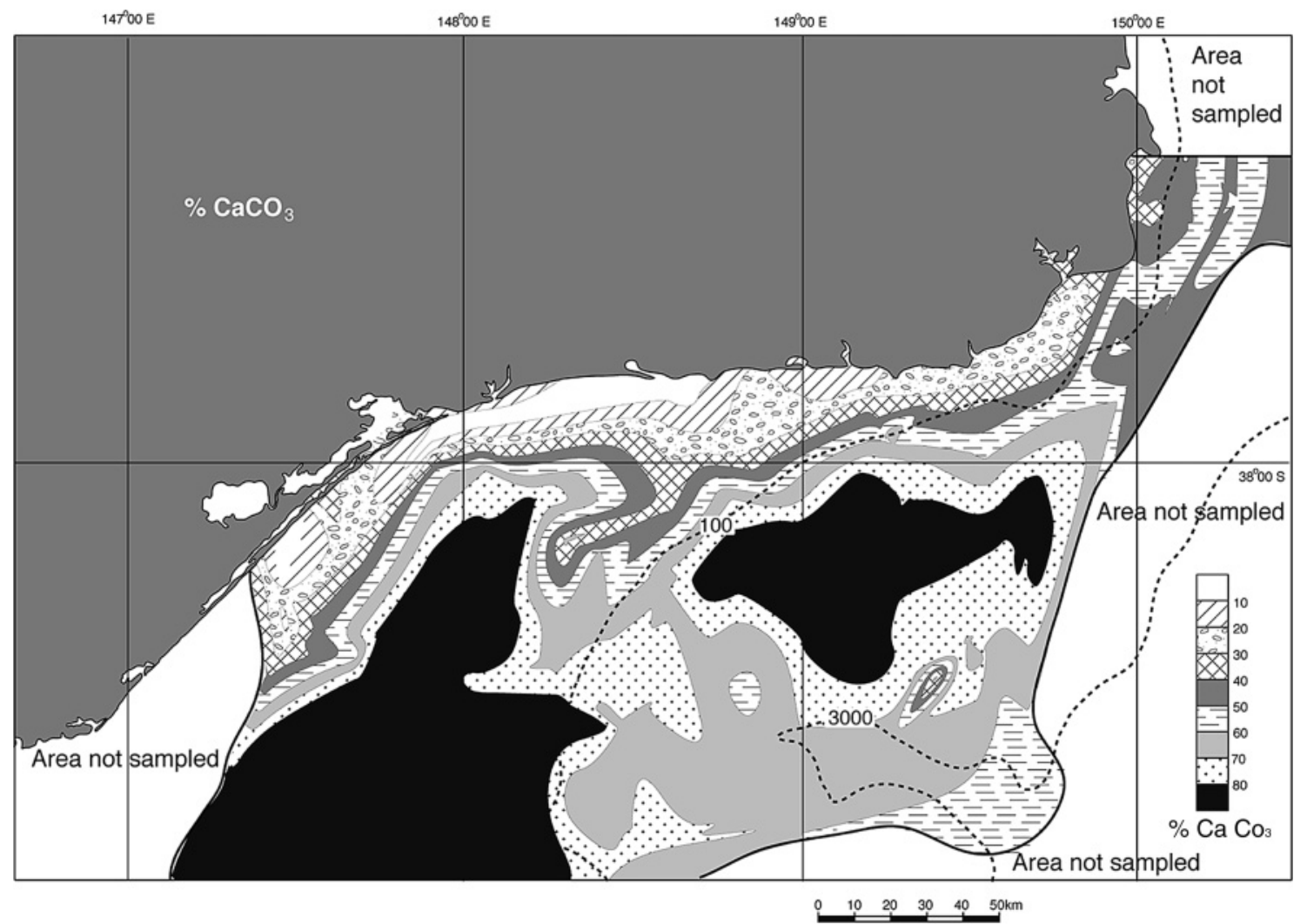

Fig. 4. The percentage of carbonate in the Gippsland Basin, using data from Smith (2001), GA data from the Southern Surveyor (SS01/00) and data published in Jones \& Davies (1983).

calcium carbonate of the shelf to bathyal realm in southeastern Australia. This map uses data obtained from this study, along with GA (Geoscience Australia) data derived from the Southern Surveyor (Harris et al., 2000) and data from Jones \& Davies (1983).

The Gippsland Lakes and the inner shelf yields between 0 and $40 \%$ calcium carbonate, where values are increasing with depth (Fig. 4). This is due to the abundance of siliciclastic sediments in the shallow facies and the relative lack of calcium carbonate producing organisms. This carbonate low stretches along the coast caused by the longshore drift distribution of siliciclastic sediments. From the middle to outer shelf, the calcium carbonate percentage increases with depth, due to dilution of clastic sediments with an increasingly diverse bioclastic assemblage. This is the cool-water carbonate 'factory', the region where particles of all grain sizes are 'born', either by crystallising as skeletons or precipitating directly out of the seawater (James \& Kendall, 1992). The relatively low calcium carbonate values in the middle shelf, southeast of Lakes Entrance may be caused by the presence of remnant siliciclastics derived from palaeo-rivers, which meandered across the Pliocene to Pleistocene coastal plain during glacial period(s).

There are two clear calcium carbonate-rich areas due south of the Gippsland Lakes and north of the Bass Canyon (Fig. 4). These sediment-starved regions are densely populated by bryozoans with both living and fossil forms comprising most of the bioclasts in the carbonate 'factory'.

A carbonate high to the north of the Bass Canyon occurs near the outer shelf to upper slope transition. This bryozoan-rich facies is similar to that described by Wass et al. (1970), who observed that living bryozoa are most abundant at depths between 90 and $220 \mathrm{~m}$ in southern Australia. High carbonate values are also recorded from deeper, bathyal Globigerina ooze sediments (Fig. 4).

The carbonate low on the northern side of the Bass Canyon may be due to erosion of the steep canyon wall, possibly exposing and reworking parts of the underlying, carbonate poor, lower Tertiary Latrobe Group.

Carbonate values decrease in the deeper part of the canyon due to the abundance of clay and since the deeper samples are taken from below the carbonate compensation depth (CCD). The CCD is estimated to be around $3600 \mathrm{~m}$ based on the results of two stations: north-east of Sydney and south-east of Tasmania (Tilbrook, pers. comm.).

The percentage gravel, sand and mud size (Folk and Dunham classification) contour maps (Fig. 5) are derived from GA data from the Southern Surveyor cruise (Harris et al., 2000) and data published in Jones and Davies (1983). These percentages are based on bulk samples; they refer to grainsize percentages and do not distinguish between siliciclastic and bioclastic grains.

Figure 5a shows a high percentage of gravel in the western section of the area of study. This is associated with the carbonate high shown in Figure 4 due to the presence of bryozoan-rich sediments. Most of the shelf and slope to the northeast of the Bass Canyon yields low $(<5 \%)$ gravel percentages where this region is carbonate-rich (Fig. 4). Here the bioclasts in the sediments are sand sized or smaller, perhaps due to the 
Recent foraminifera from Gippsland Basin, Australia
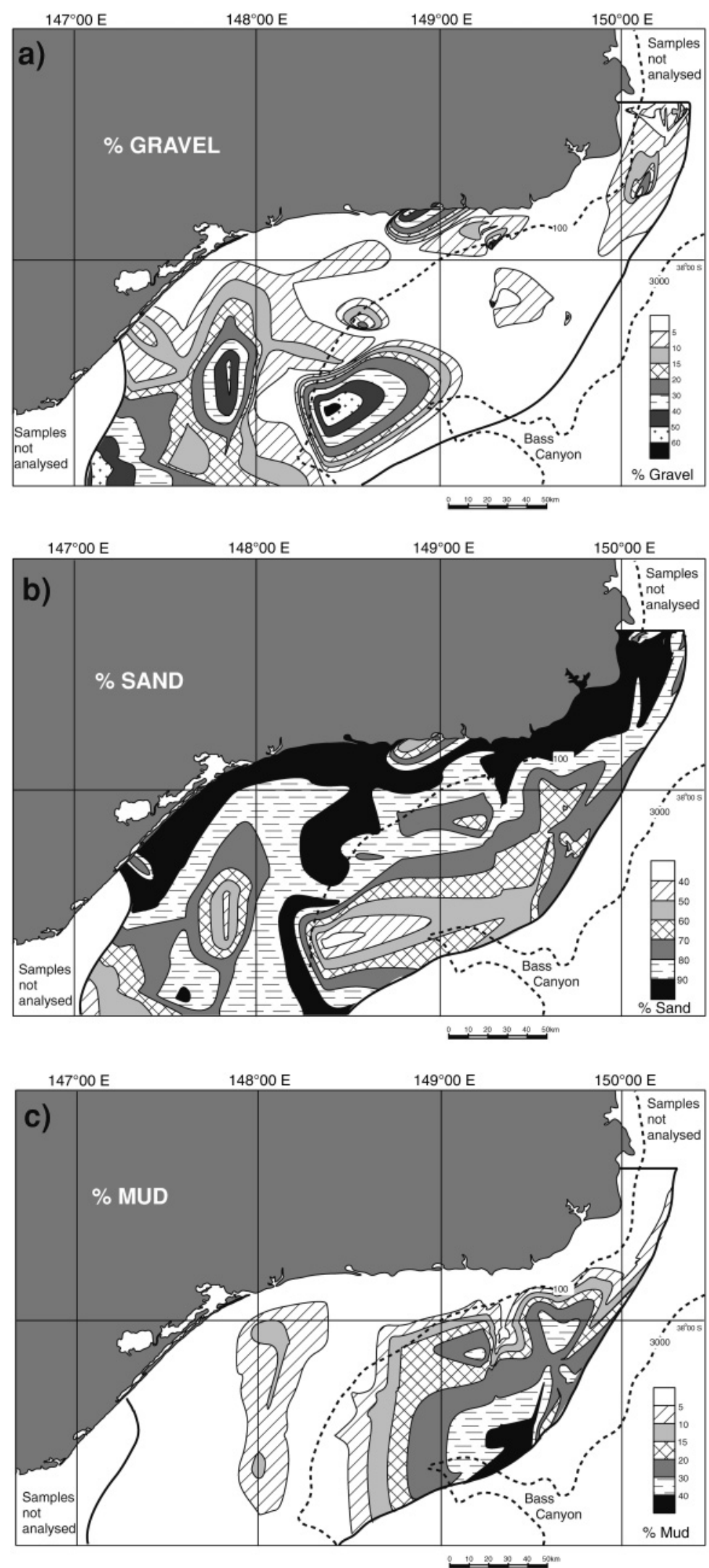

Fig. 5. The percentage of a) gravel, b) sand and c) mud size sediments in the Gippsland Basin, using GA data from the Southern Surveyor (SS01/00) and data published in Jones \& Davies (1983). 
instability of the relatively steep shelf/slope environment that did not allow bryozoans and other bioclast-producers to thrive. There is a lobe of gravel-rich sediments on the inner shelf towards the centre of the area of study, this is associated with low inner-shelfal carbonate percentages (Fig. 4) and abundant quartz grains, and may be a related to the reworking and transportation of terrestrial material. The lobe of gravel-rich sediments extending from the middle shelf to the Bass Canyon head may be associated with downslope transport of bioclasts.

The contour map of sand-sized siliciclastics and bioclasts (Fig. 5b) shows an inverse relationship to \% gravel, where the highest percentages of sand-size sediments occur in the inner to middle shelf, replaced by mud in deeper facies. The high \% sand values along the inner shelf are probably related to longshore drift and entrainment of the Ninety Mile Beach sediments. The high percentage sand values, which extends south from the coast along the $148^{\circ} 30^{\prime} \mathrm{E}$ latitude, matches the carbonate low in this region (Fig. 4) and is possibly related to remnant river sediments.

The contour map of $\%$ mud in southeastern Australia (Fig. $5 c)$ shows an increase in abundance with increased depth. The most abundant mud-sized sediments $(>40 \%)$, occur at depths greater than $2000 \mathrm{~m}$, where Globigerina ooze predominates, yielding 60 to $70 \%$ carbonate (Fig. 4). There is a lobe of calcareous mud stretching outward from Lakes Entrance. This corresponds with high shallow water percentage gravel values, where poorly sorted bioclasts in a muddy matrix accumulate, reflecting the overall low energy nature of the shelf.

\section{BENTHIC FORAMINIFERAL DISTRIBUTION IN THE BASS CANYON}

\section{Shelfal biofacies}

The neritic samples were obtained from middle to outer shelf depths. The shallow samples on Transect C (88, 132 and $145 \mathrm{~m})$ (Fig. 6) are dominated by rotaliids and miliolids, with Cibicides mediocris, Cibicides refulgens, Quinqueloculina spp., Dyocibicides biserialis, Elphidium macelliforme, E. crispum and Uvigerina bassensis. Up to $12 \%$ of the benthic (live + dead) assemblage are textulariids, including Textularia sagittula, Gaudryina quadrangularis, and Gaudryina convexa. Between 14 and 30\% of the benthic foraminifera in these assemblages were living at the time of collection. Relict foraminifera comprise 9 to $22 \%$ of the total benthic assemblages. The shallower shelf samples yielded diversity values from 15 to 17 (Margalef diversity, Appendix 1).

The deeper shelf samples on transect $\mathrm{C}$ (Fig. 6) are dominated by rotaliids, with common C. mediocris, Hoeglundina elegans, Lenticulina spp., Parrellina imperatrix and U. bassensis. Miliolids comprise 6 to $15 \%$ of the benthic (live + dead) assemblages and textulariids make up between 6 and $9 \%$ of these assemblages. Up to $11 \%$ of the benthic (live + dead) assemblages were found to be alive at time of collection. Few relict forms occur.

The shelf samples on transect D (Fig. 7) consist predominantly of rotaliids, principally Astrononion centroplax, C. mediocris, Discorbinella spp., Globocassidulina subglobosa and $U$. bassensis. Miliolids (Miliolinella labiosa and Quinqueloculina spp.) are most common in the shallowest sample (132 m).

The standardized diversity of the benthic (live + dead) assemblage in these samples is between 9 and 10 . Most forms were interpreted to have been recently dead at time of collection, except for $8 \%$ live forms recorded at $132 \mathrm{~m}$.

The shelfal transect E (Fig. 8) and adjacent samples are dominated by rotaliids, with abundant $H$. elegans, Lenticulina spp., $P$. imperatrix and $C$. mediocris. Miliolids account for up to $25 \%$ and textulariids up to $21 \%$ of the benthic (live + dead) assemblages. The Margalef diversity index for this section is between 10 and 13. Between 7 and $9 \%$ of the benthic (live + dead) fauna at $119 \mathrm{~m}(\mathrm{~K} 7 / 73 / 19)$ and $223 \mathrm{~m}(\mathrm{~K} 7 / 73 / 20)$ are interpreted to have been alive at the time of collection. Minor relict forms occur at $223 \mathrm{~m}$.

\section{Oxic upper to middle slope biofacies}

Benthic foraminifera comprise up to $32 \%$ of the total foraminiferal assemblages in the upper to middle bathyal oxic zone, decreasing with depth. Parrellina imperatrix, Rosalina spp. and Uvigerina spp. are common in the shallower samples, while A. centroplax, C. mediocris, $H$. elegans, Lenticulina spp. and G. subglobosa occur between 366 and $1137 \mathrm{~m}$ (Figs 6, 7 \& 8). Foraminifera interpreted to have been alive at the time of collection were rare deeper than $600 \mathrm{~m}$. No relict forms occurred in the oxic upper to middle slope biofacies. Faunal diversity was found to decrease with depth into the bathyal realm.

\section{Slope biofacies in the reduced-oxygen zone}

Samples from the bathyal reduced-oxygen zone yielded between 8 and 19\% benthic foraminifera. Rotaliids include Bulimina marginata, Bolivinita quadrilatera and Anomalinoides spp. The dominant textulariid taxa include Rhabdammina agglutissima and Reophax spp. Faunal diversity is relative low in this biofacies (Figs 6, $7 \& 8$ ).

\section{Oxygenated middle to lower slope}

Benthic foraminifera increase in abundance from 2 to $17 \%$ with increasing depth in this zone. Typical rotaliids include Cibicidoides wuellerstorfi, Sphaeroidina bulloides, B. marginata and Gyroidinoides spp. Textulariids are abundant in the lower bathyal samples (3114, 3340 and $3931 \mathrm{~m}$ ), dominated by Rhabdammina spp., Rhizammina spp., Reophax spp., Marsipella spp. and Hyperammina spp. The miliolids Pyrgo lucernula and Pyrgo serrata also occur in the deeper samples. Benthic diversity in this interval is low (Figs 6, $7 \& 8$ ). Refer to Plates 1 and 2 for images of the most common species of benthic foraminifera mentioned above.

\section{PLANKTONIC FORAMINIFERAL DISTRIBUTION IN THE BASS CANYON}

\section{Shelfal biofacies}

The neritic realm on the margin of the Bass Canyon is plankton poor in its shallowest parts (8\%), with yields of up to $60 \%$ in the deeper outer shelf. Globorotalia inflata dominates the planktonic fauna with common Globigerina bulloides (Figs 6, 7 \& 8).

\section{Oxic upper to middle slope biofacies}

Planktonic foraminifera are abundant, increasing from 68 to $96 \%$ with depth. Globorotalia inflata dominates the planktonic fauna with lesser amounts of G. bulloides, Globorotalia hirsuta, 
Recent foraminifera from Gippsland Basin, Australia
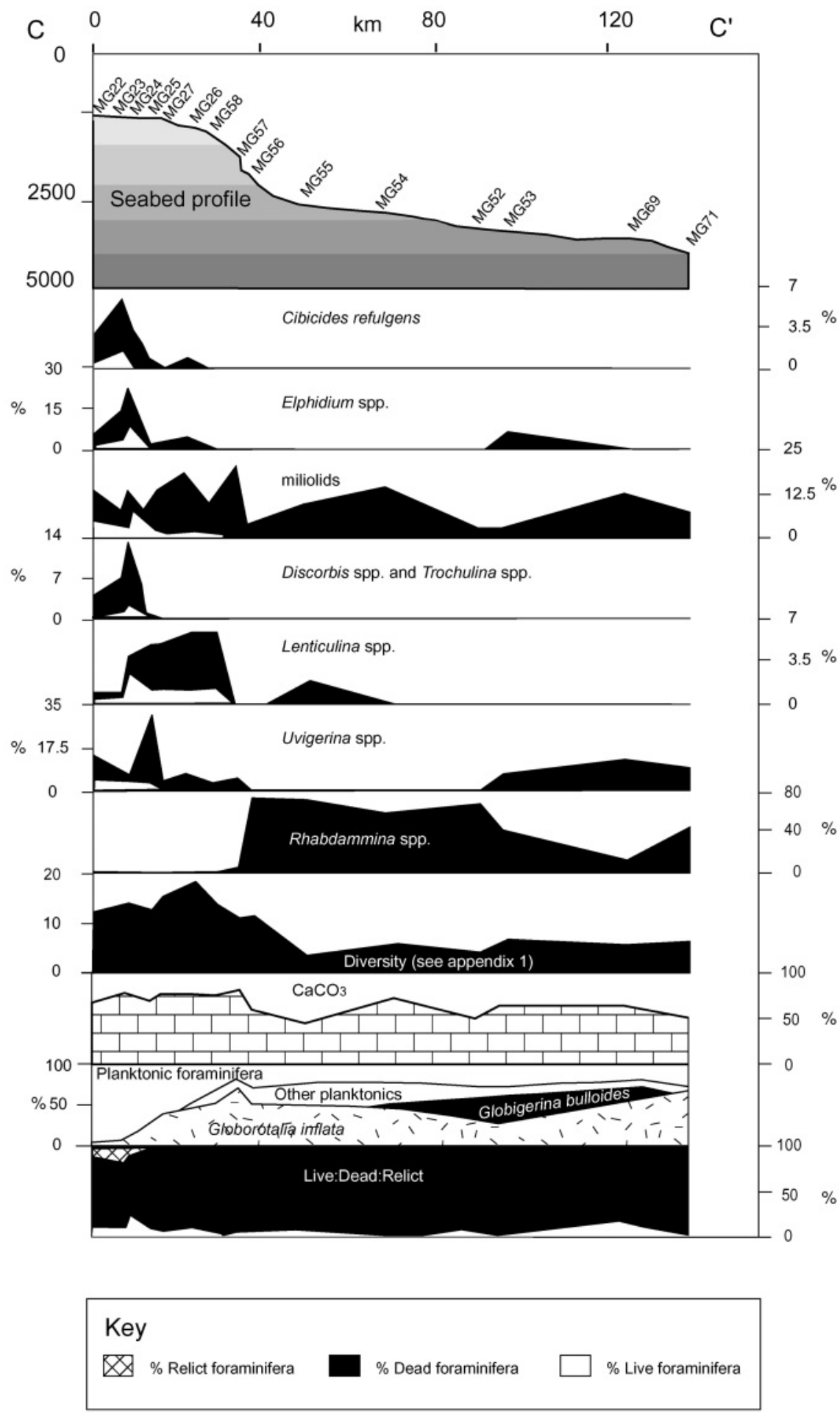

Fig. 6. Transect C. Bivariate graphs show abundance and distribution of various taxa as percentage of the biococenosis, the live + dead assemblages. Diversity as shown is the Margalef diversity (see Appendix 1). The total abundance of planktonic foraminifera are calculated as percentages of the benthic (live + dead) and planktonic assemblages, with the relative percentages of Globigerina bulloides, Globorotalia inflata and other planktonics (which include all species of planktonic foraminifera other than G. bulloides and G. inflata) shown as percentages of the planktonic assemblages. The Live:Dead:Relict abundances are shown as part of the thanatocoenosis, the entire benthic assemblage (see Fig. 1 for location of samples shown in seabed profile). 
D

D'
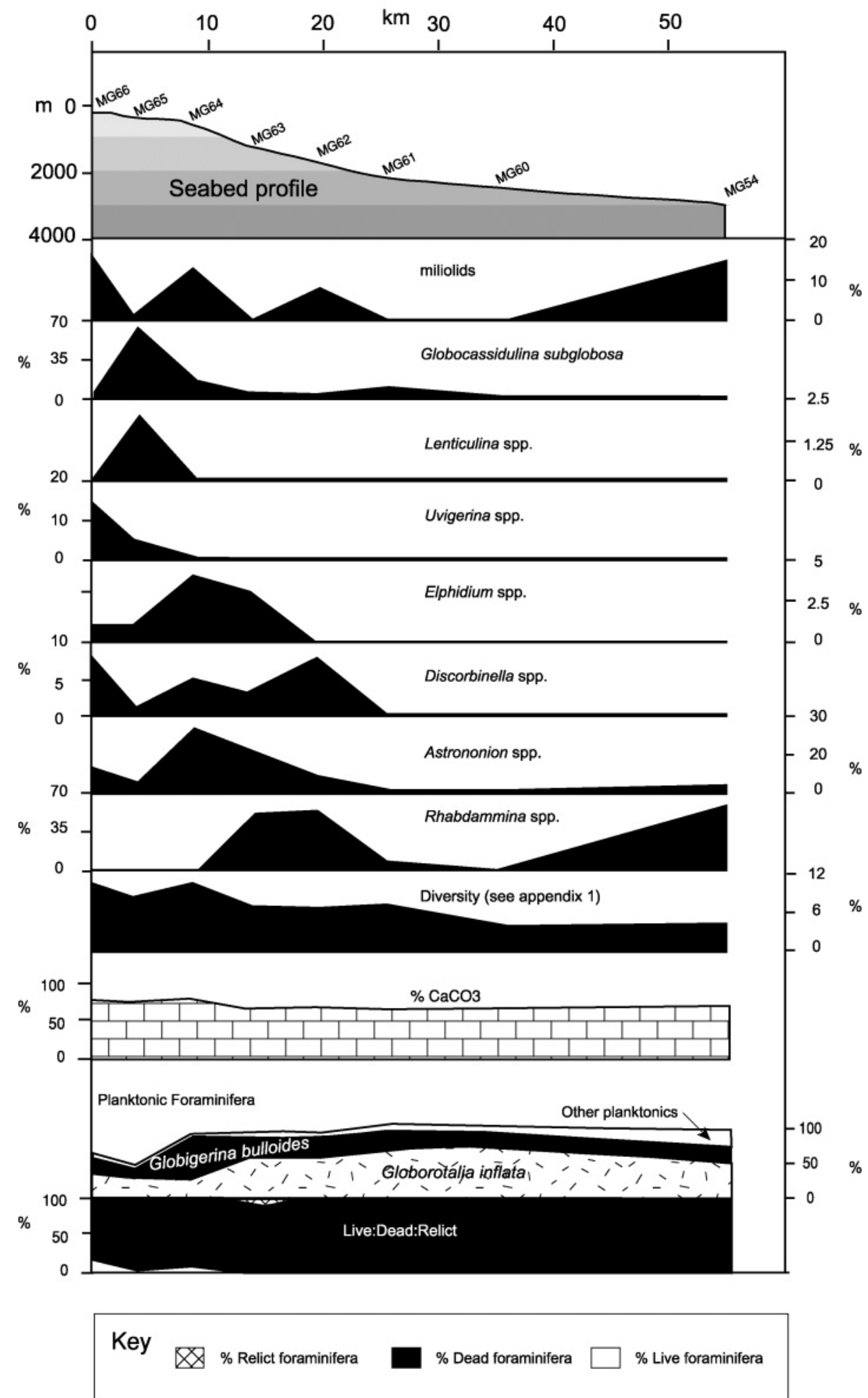

Fig. 7. Transect D. Bivariate graphs show abundance and distribution of various taxa as percentage of the biococenosis, the live + dead assemblages. Diversity as shown is the Margalef diversity (see Appendix 1). The total abundance of planktonic foraminifera are calculated as percentages of the benthic (live + dead) and planktonic assemblages, with the relative percentages of Globigerina bulloides, Globorotalia inflata and other planktonics (which include all species of planktonic foraminifera other than $G$. bulloides and G. inflata) shown as percentages of the planktonic assemblages. The Live:Dead:Relict abundances are shown as part of the thanatocoenosis, the entire benthic assemblage (see Fig. 1 for location of samples shown in seabed profile) 
Recent foraminifera from Gippsland Basin, Australia
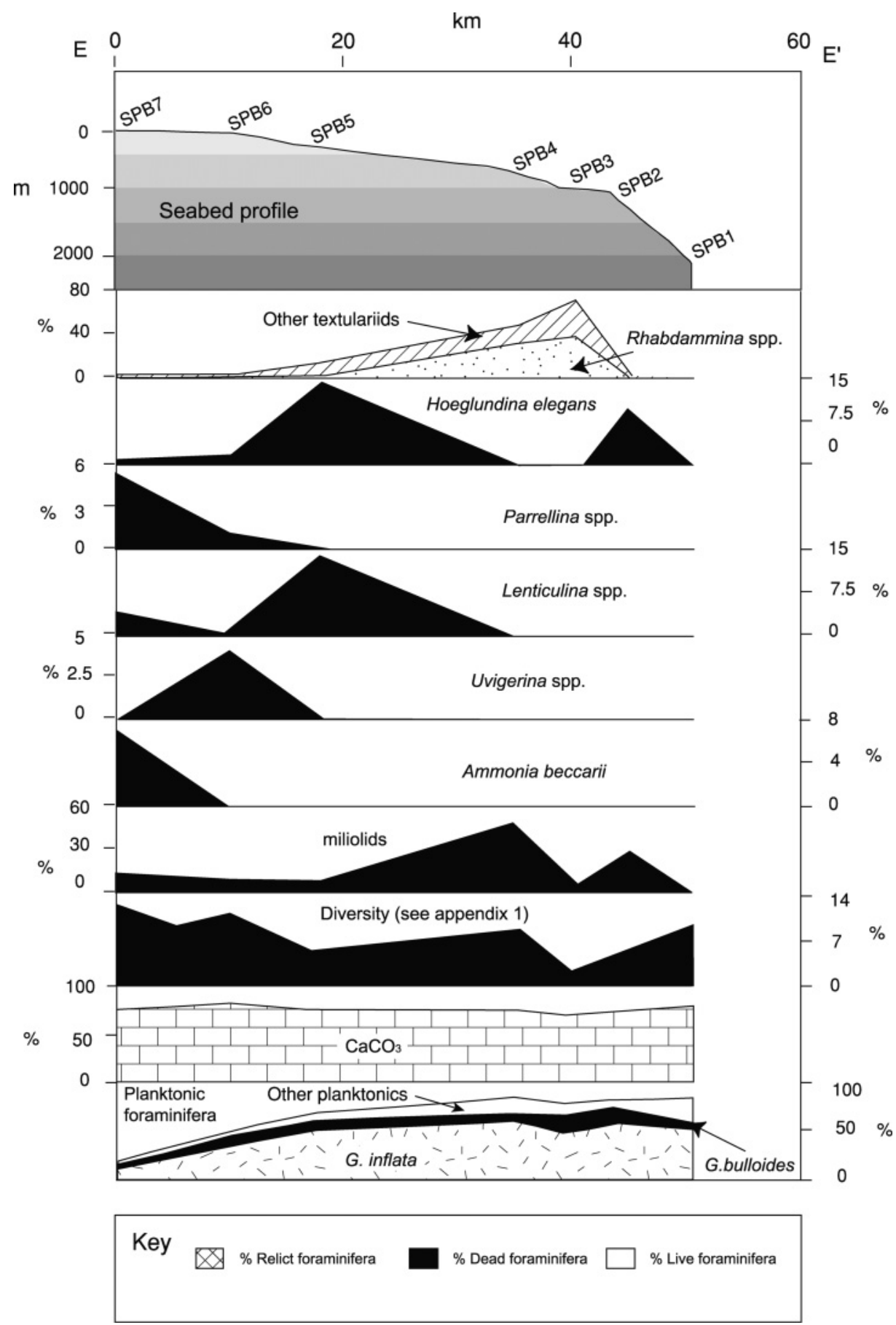

Fig. 8. Transect E. Bivariate graphs show abundance and distribution of various taxa as percentage of the biococenosis, the live + dead assemblages. Diversity as shown is the Margalef diversity (see Appendix 1). The total abundance of planktonic foraminifera are calculated as percentages of the benthic (live + dead) and planktonic assemblages, with the relative percentages of Globigerina bulloides, Globorotalia inflata and other planktonics (which include all species of planktonic foraminifera other than $G$. bulloides and G. inflata) shown as percentages of the planktonic assemblages. The Live:Dead:Relict abundances are shown as part of the thanatocoenosis, the entire benthic assemblage (see Fig. 1 for location of samples shown in seabed profile).

Globorotalia truncatulinoides, Globigerinoides rubber, Orbulina universa and Globorotalia (Figs 6, 7 \& 8).

Slope biofacies in the reduced oxygen zone

A similar planktonic foraminiferal assemblage to the middle to upper bathyal oxygenated zone occurs in this interval.
Oxygenated middle to lower slope

Planktonic foraminifera are abundant in this interval, comprising 83 to $98 \%$ of the entire assemblage. Globorotalia inflata is dominant except at $3340 \mathrm{~m}$ (MG53) where the assemblage is dominated by $G$. bulloides. Globorotalia hirsuta, G. truncatulinoides, G. ruber, Orbulina universa, Neogloboquadrina dutertrei, 


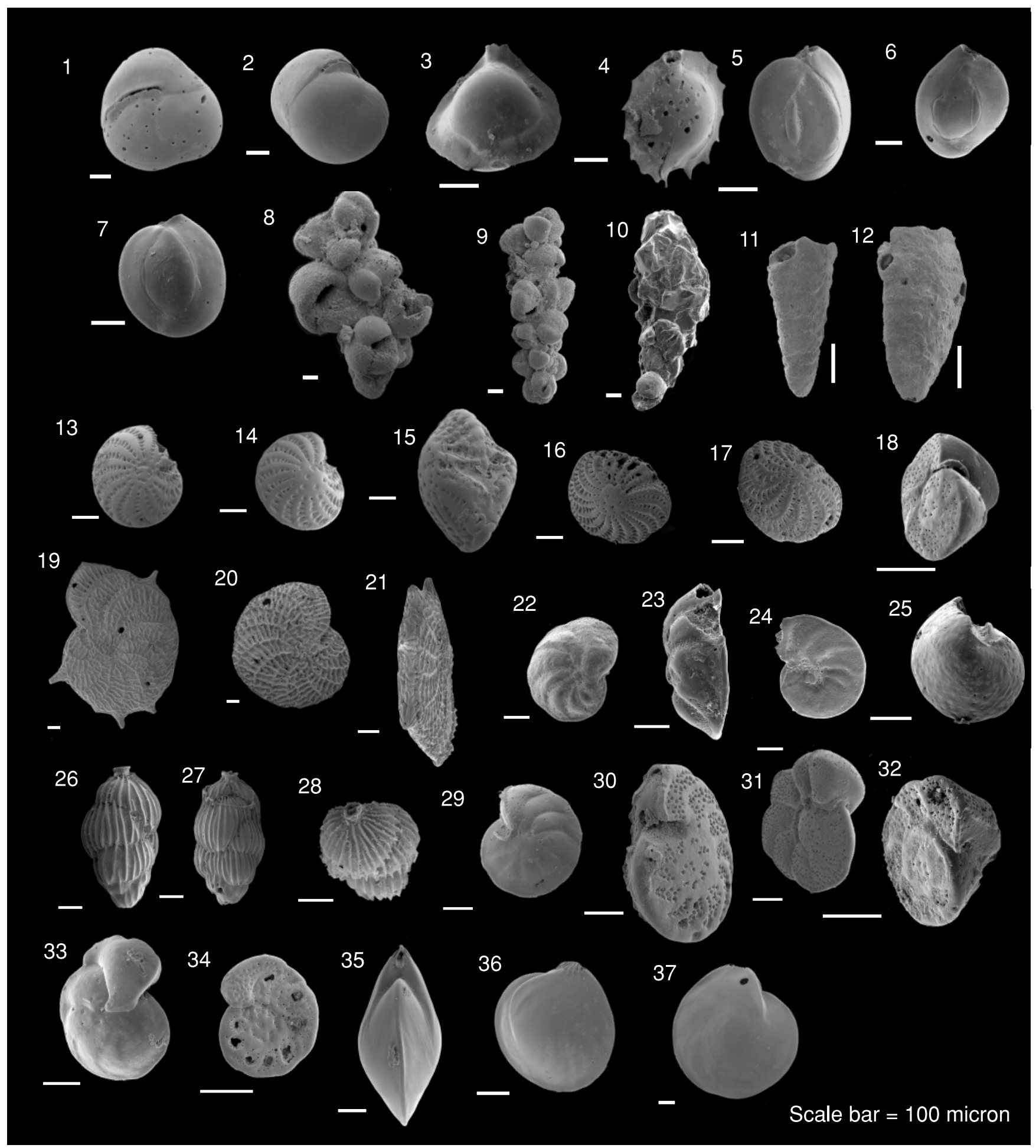

Explanation of Plate 1.

figs. 1-2. Miliolinella australis (Parr, 1932), MG24, 145 m, Franklin, 1998, aperture and side view. fig. 3. Pyrgo lucernula (Schwager, 1866); MG71, 3931 m, Franklin, 1998, side view. fig. 4. Pyrgo serrata (Bailey, 1862); MG71, 3931 m, Franklin, 1998, figs 5-7. Quinqueloculina lamarkiana d'Orbigny, 1839; MG15, 62 m, Franklin, 1998, side and aperture views. figs 8-9. Rhabdammina agglutissima Hofker, 1972; MG55, 2980 m. Franklin, 1998, side view. fig. 10. Reophax scorpiurus de Montfort, 1808, SM31, 112 m, Southern Surveyor, 2000, side view. figs 11-12. Textularia sagittula Defrance, 1824, MG10, 42.5 m, Franklin, 1998, side views. figs 13-15. Elphidium advenum (Cushman, 1922); MG23, 134 m, Franklin, 1998, side and aperture views. figs 16-17. Elphidium crispum (Linne, 1758); MG23, 134 m, Franklin, 1998, side views. figs 19-21. Parrellina imperatrix (Brady, 1881); MG49, 190 m, Franklin, 1998, side and axial views. figs 22-24. Discorbinella bertheloti (d'Orbigny, 1839); SM12, 112 m, Southern Surveyor, 2000, spiral, axial and umbilical views. figs 26-28. Uvigerina bassensis Parr, 1950; MG25, 242 m. Franklin, 1998, side, axial and rear views. figs 29-31. Cibicides mediocris Finlay, 1940; MG21, 84 m, Franklin, 1998, spiral, axial and umbilical views. figs 18, 25, 32. Cibicides refulgens de Montfort, 1808; MG31, 52.5 m, Franklin, 1998, spiral, axial and umbilical views. figs 33-34. Cibicidoides wuellerstorfi (Schwager, 1866); MG71, $3931 \mathrm{~m}$, Franklin, 1998, spiral and axial views. figs 35-37. Lenticulina limbosa (Reuss, 1863); MG24, 145 m, Franklin, 1998, side and axial views. 


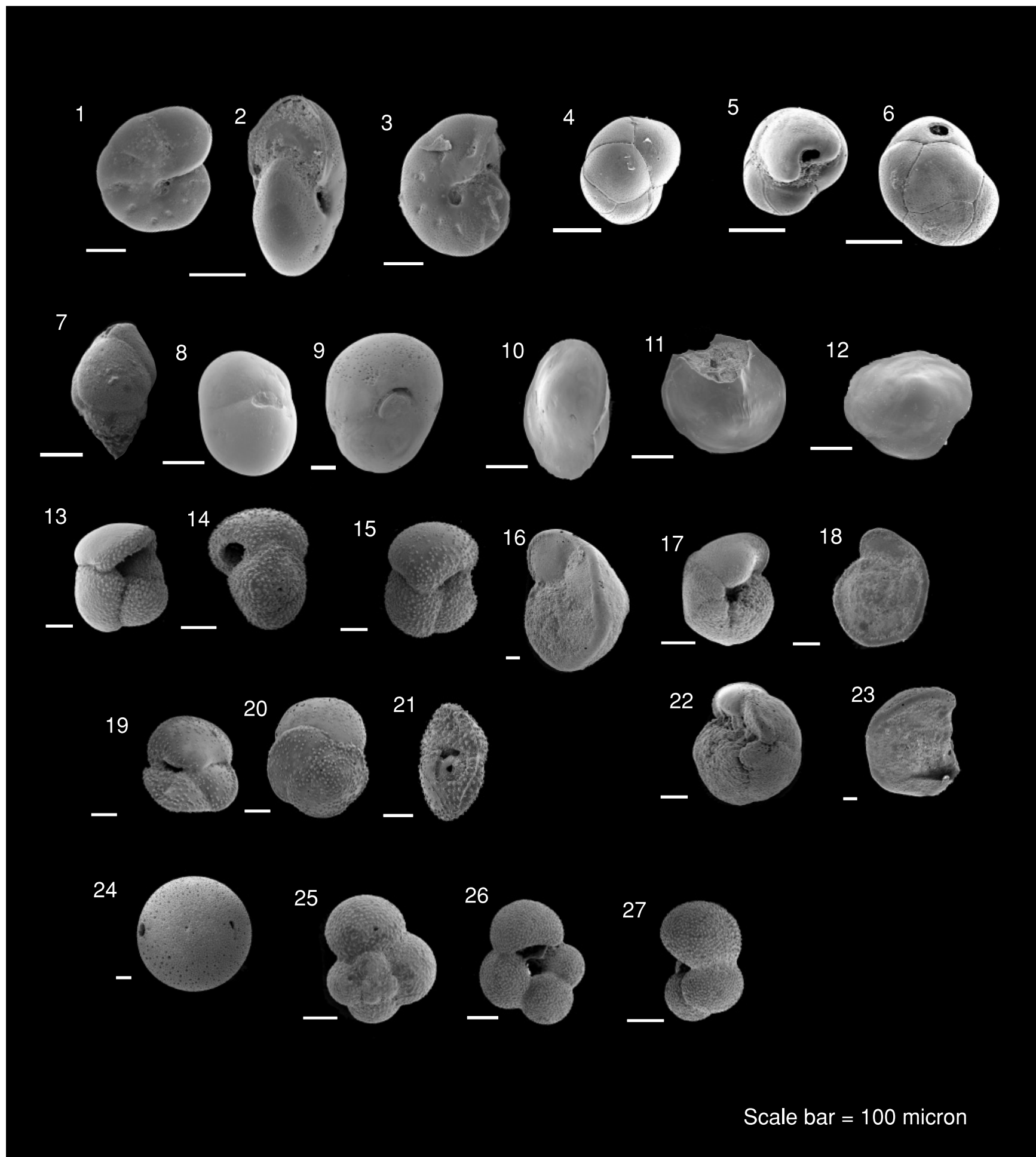

Explanation of Plate 2.

figs 1-3. Astrononion centroplax Carter, 1958, MG24, 170 m, Franklin, 1998, side and axial views. figs 4-6. Globocassidulina subglobossa (Brady, 1881), MG65, 300 m, Franklin, 1998, side and aperture views. fig. 7. Bulimina marginata d'Orbigny, 1826, MG71, 3931 m, Franklin, 1998. side view. figs 8-9. Sphaeroidina bulloides d'Orbigny, 1826; MG25, $242 \mathrm{~m}$, Franklin, 1998, side and aperture views. figs 10-12. Hoeglundina elegans (d'Orbigny, 1826); MG58, 603 m, Franklin, 1998, side, axial views. figs 13-15. Globorotalia inflata (d'Orbigny, 1839); MG51, 279 m, Franklin, 1998 ; Flounder 2, 79 m, umbilical, spiral and axial views. figs 16-18, 22-23. Globorotalia truncatulinoides (d'Orbigny, 1839); MG51, 276 m, Franklin, 1998, umbilical, spiral and axial views. (16, 17, 18 - left coiling; 22, 23 - right coiling). figs 19-21. Globorotalia hirsuta (d'Orbigny, 1839); MG51, 276 m, Franklin, 1998, umbilical, spiral and axial views. fig. 24. Orbulina universa d'Orbigny, 1839; MG51, 276 m, Franklin, 1998. figs 25-27. Globigerina bulloides d’Orbigny, 1826; MG51, 279 m, Franklin, 1998, umbilical, spiral and axial views. 
Globorotalia scitula, Globigerinella siphonifera and G. crassula are also present in this interval (Figs 6, $7 \& 8$ ). Refer to Plate 2 for images of the most common species of planktonic foraminifera mentioned above.

\section{CORRESPONDENCE ANALYSIS}

Correspondence analysis (CA) is an eigenvector method which allows the projection of a large multivariate cloud of points (samples, parameters or both) into a very reduced space (defined by the factor axes) while conserving the major part of the structured, meaningful information (Hennebert \& Lees, 1991). The result is a two-dimensional graph where similar samples or parameters (or both) are nearest each other and those which are most dissimilar furthest apart. Correspondence Analysis calculates the variation (as a percentage) represented by each axes, and assigns a Relay Index (RI) to each sample or component, these values are rescaled such that the range RI's lies between 0 and 100 (Pickard \& Emery, 1990).

The method is useful in detecting environmentally important trends in foraminiferal assemblage data. If a uni-dimensional variation trend such as a depth relay exists in the data set, projection of the results of CA onto a factorial plane (defined by the first and second CA axes) should produce an Arch effect or Guttman effect (Pickard \& Emery, 1990). Correspondence Analysis has been applied successfully to modern and ancient carbonate facies analysis by Melguen (1974) and Hennebert \& Lees (1991), Carboniferous limestones by Pickard \& Emery (1990) and Carboniferous foraminiferal studies by Gallagher (1997). The computer packages utilized to carry out the analysis on this data, SedUTIL (used to store the data) and AFCal (a correspondence analysis package) were created by Lees (1989).

Figure 9 shows the correspondence analysis results for the 36 samples studied from the Bass Canyon, and Figure 10 shows a CA plot of the parameters included in this analysis. The percentage abundance of 61 parameters in each of the 36 samples were included in the analysis: 44 were the most common benthic foraminiferal taxa, 11 were the most common planktonic foraminiferal taxa, other parameters include the total percentages of the four supergroups, 'undifferentiated foraminifera' and the $\% \mathrm{CaCO}_{3}$ (note, only 40 of the most useful parameters are annotated for clarity).

Before beginning analysis on the CA data, the proportion of inertia of each of the axes must be considered. The calculated inertia of the three axes is $38.0 \%, 26.4 \%$ and $9.7 \%$ respectively for axes one, two and three, totalling $74.1 \%$. If values greater than $30 \%$ are obtained for the first axis, or if the total statistical variation accounted for the three axes is over $50 \%$, then the results of the analysis are useful and a statistically significant arched plot is obtained (Gallagher, 1997).

The scatter of points on the CA plot is clearly related to depth, with the shelfal samples plotted on the left side of the graph and the lower slope cluster on the right. The three shallower samples (MG22, MG23 and MG24) contain a significantly different assemblage to the other middle to outer shelf samples included in this analyses, causing the statistical separation of this cluster. Although depth seems to be the dominant control on the distribution of faunas and parameter points on the correspondence analyses plot, it is not the only controlling

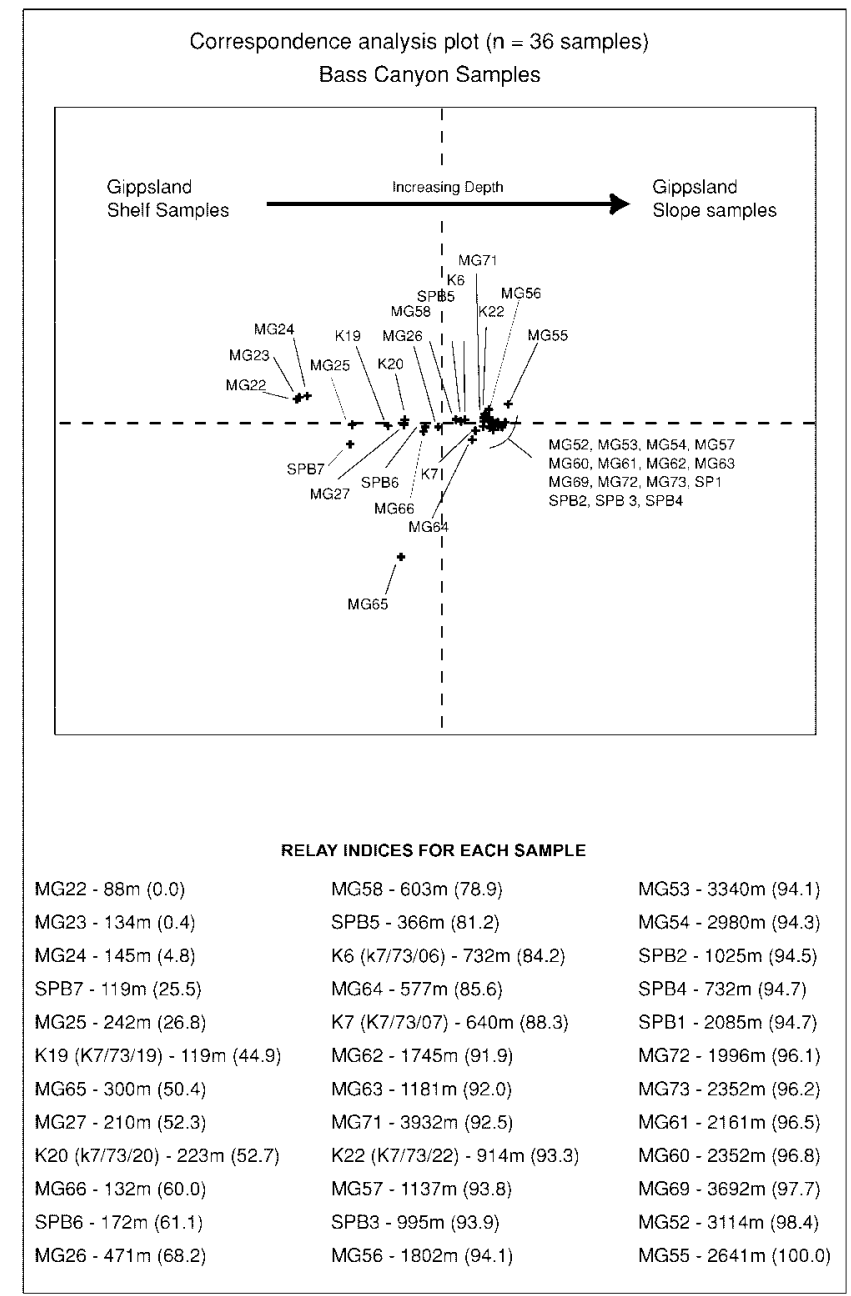

Fig. 9. Results of the correspondence analysis of 36 samples from the Bass Canyon. The parameter used for this analysis are listed in Fig. 10.

factor, with other closely related parameters, such as dissolved oxygen and substrate, exerting control, as shown below.

Samples from $1137 \mathrm{~m}$ (MG57, transect C) and $1181 \mathrm{~m} \mathrm{(MG}$ 63 , transect D) contain similar foraminiferal assemblages yielding Relay Indices of 92.0 and 93.8 respectively, since both samples are molluscan-foraminiferal clay to fine sand. Samples from $366 \mathrm{~m}$ (SPB5, transect E) and $577 \mathrm{~m}$ (MG64, transect D), despite being derived from different depths, contain similar assemblages (with RI's of 81.2 and 85.6) where both samples comprise silt containing molluscs, foraminifera and peloids. In addition, the samples from $134 \mathrm{~m}(\mathrm{MG}, 23$, transect $\mathrm{C})$ and $132 \mathrm{~m}$ (MG66, transect D), yield different assemblages, with RI's of 0.4 and 60.0 respectively, have contrasting facies: MG23 is a fine to medium sand containing molluscs, bryozoa, foraminifera and quartz fragments and MG66 is a silt containing molluscs, bryozoa, foraminifera and sponge spicules.

There is less variability in the assemblages of the deeper samples $(>1000 \mathrm{~m})$ compared to the shallower samples $(<1000 \mathrm{~m})$. The deeper samples' RI values range from 91.9 to 100.0, whereas the shallower samples' RIs values range from 0.0 to 93.3 . This is partly due to decreased diversity and increased plankton percentage with depth (Figs 6, 7 \& 8). 


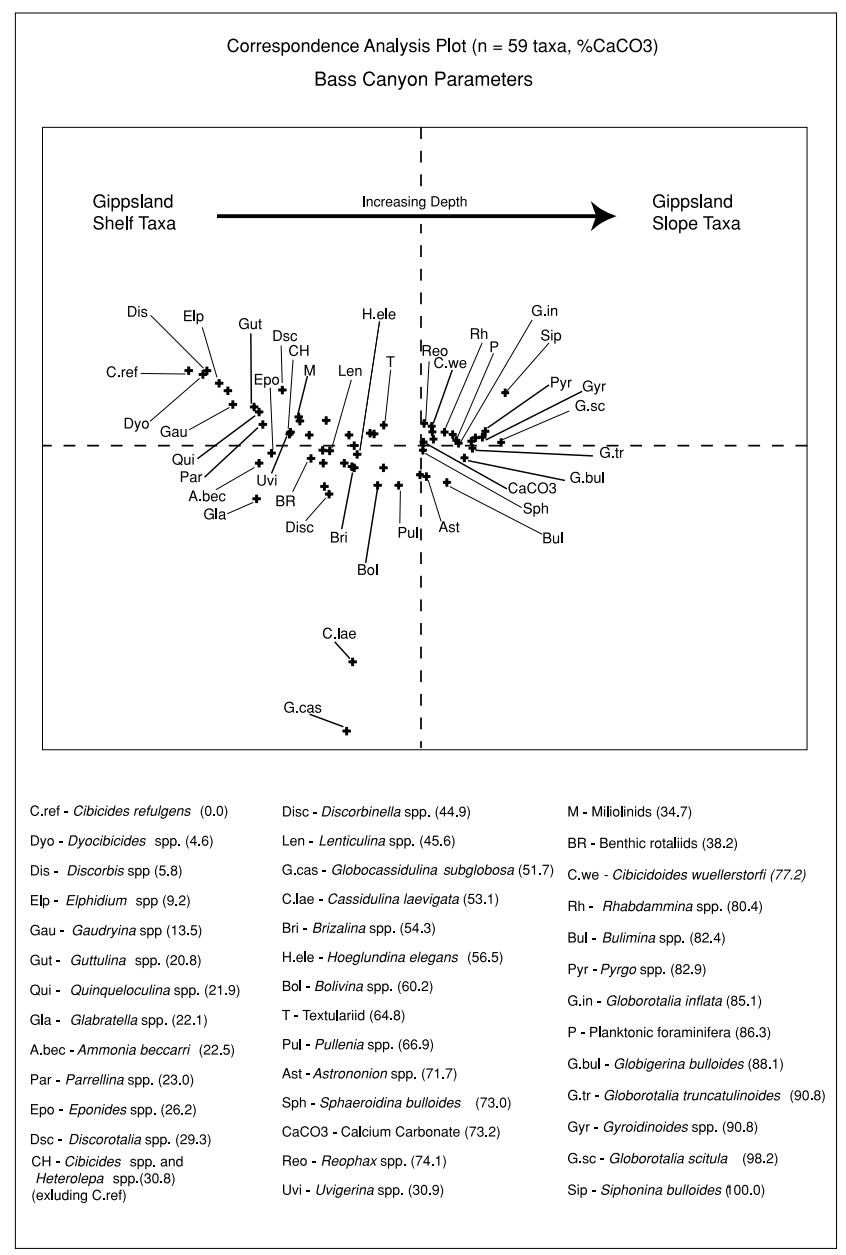

Fig. 10. Results of the correspondence analysis of 61 parameters in 36 samples from the Bass Canyon. The samples used for this analysis are listed in Fig. 9.

Planktonic foraminifera account for at least $80 \%$ of the total assemblage in all samples deeper than $1000 \mathrm{~m}$, and only a total of 11 species of planktonic foraminifera occur in this region.

The middle to outer shelf assemblage of Figure 10 contains Cibicides refulgens, Elphidium spp. and Discorbis spp. Typical shelf break to slope fauna includes Hoeglundina elegans and Lenticulina spp. The slope assemblage includes Cibicidoides wuellerstorfi, Pyrgo lucernula, Pyrgo serrata, Rhabdammina spp. and Gyroidinoides spp., taxa that can tolerate reduced oxygenated conditions. Similar distributions elsewhere for these taxa were noted by Pflum et al. (1976), Loeblich \& Tappan (1987), Murray (1991), Yassini \& Jones (1995), Li et al. (1996a, b) and Hayward et al. (1999).

Globocassidulina subglobosa and Cassidulina laevigata occur as outliers due to their dominance in MG65 (300 m) where they account for $40 \%$ of the entire assemblage, suggesting ideal conditions for these species.

\section{DISCUSSION}

The distribution of the foraminiferal taxa in the Bass Canyon will be discussed in this section. Figure 11 summarizes the distribution of the most common benthic foraminiferal species incorporating quantitative data from transects and correspondence analyses results. In addition, the occurrence of foraminifera interpreted to have been living at time of collection, as well as relict specimens are shown.

The distribution and abundance of Cibicides, the most common benthic genus in southeastern Australia (Smith et al., 2001), is similar to the percentage carbonate, which itself is related to abundant bryozoans. This suggests that Cibicides prefers bioclast-rich sediments on which to attach themselves. Foraminiferal diversity also displays a similar pattern to the percentage of carbonate, with the highest diversity occurring in the 'carbonate factory'.

The epifaunal Cibicides refulgens occurs in samples shallower than $145 \mathrm{~m}$ on transect C. This taxon is substrate controlled, most commonly found on bioclastic sands, where it attaches itself to hard substrates (Smith et al., 2001). The distribution of C. refulgens is inversely related to Uvigerina on this transect. Uvigerina is restricted to the neritic and outer neritic zones in the Bass Canyon. The percentage of $\mathrm{CaCO}_{3}$ is related to the nature of the substrate, with higher values reflecting the presence of bioclast-rich carbonates and coarser grained bioclastic substrates.

Lenticulina spp. occurs from the Gippsland shelf to the bathyal zone $(210 \mathrm{~m}$ to $603 \mathrm{~m})$. Parrellina spp. is present from $88 \mathrm{~m}$ to $471 \mathrm{~m}$ at the head of the Bass Canyon. The most common species of this genus is Parrellina imperatrix. The distribution and abundance of Astrononion spp. in southeastern Australia is similar to the percentage mud distribution. This is the typical substrate type for this infaunal genus (Murray, 1991). Elphidium spp. is common in the middle shelf samples, including minor relict forms. This taxon is rare deeper than $150 \mathrm{~m}$ water depth. Discorbis spp. occurs only on the shelf.

The most common benthic rotaliids in the deeper samples are Sphaeroidina bulloides, Gyroidinoides spp., Cibicidoides wuellerstorfi and Bulimina spp. Bulimina spp., like Rhabdammina spp., often inhabits reduced oxygen bottom water conditions (Sen Gupta \& Machain-Castillo, 1993). Bernhard (1986) studied benthic rotaliid assemblages from Jurassic to Holocene anoxic deposits and concluded that anaerobic taxa possess predominantly flattened, unornamented tests. The test walls are often highly perforate and thin such as in the taxon Bulimina spp. In the Bass Canyon, Bulimina spp. is most common from $1996 \mathrm{~m}$ to $2352 \mathrm{~m}$, in the reduced-oxygen zone.

Miliolids decrease in abundance with depth, with abundant relict and live fauna in the shallow samples. Quinqueloculina spp., the dominant miliolid, is most common in the shallower samples on transect C and transect E. Pyrgo lucernula and Pyrgo serrata are deep-water miliolids, occurring below $3692 \mathrm{~m}$ in the Bass Canyon.

Textulariids are geographically the most widespread group of benthic foraminifera, being well represented in marginal marine, hypersaline, hyposaline and bathyal regions (Zheng $\& \mathrm{Fu}, 1990)$. In the Gippsland Basin, Textularia saggitula, Gaudryina convexa and G. quadrangularis occur as deep as $1137 \mathrm{~m}$, although they are most common at depths less than $300 \mathrm{~m}$.

Rhabdammina spp. is present in minor quantities in the shallower samples. This is the dominant benthic taxon in the reduced-oxygen zone samples over $1000 \mathrm{~m}$ depth, often 


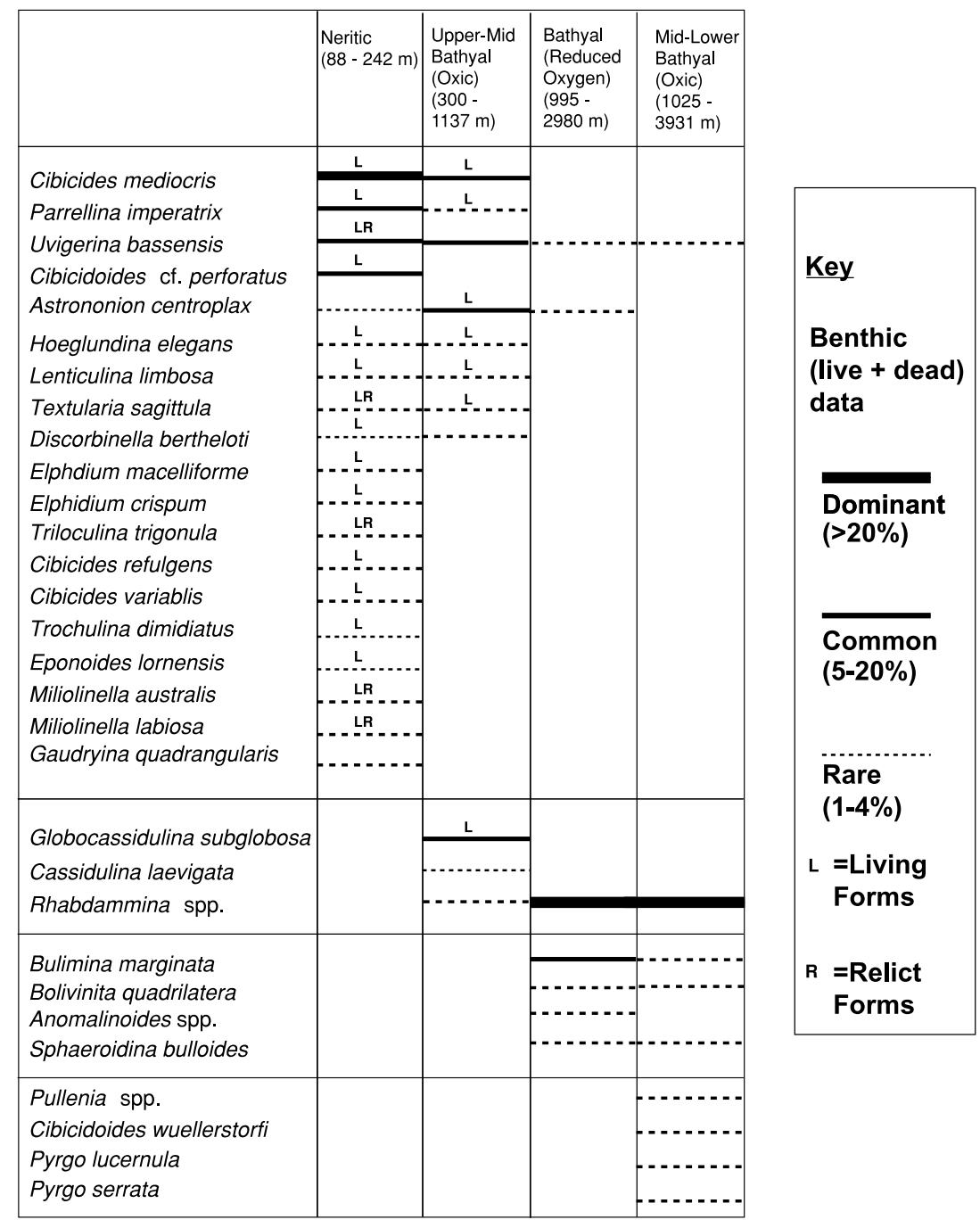

Fig. 11. An idealized summary of the distribution of benthic foraminifera in the Bass Canyon based on the results of the quantitative foraminiferal analysis and the correspondence analysis. Note: the bars represent the relative abundance of particular taxa from the benthic (live + dead) assemblages. The occurrence of relict forms are noted, however they are not used to calculate abundances.

co-occurring with Rhizammina spp. The use of these taxa as reduced-oxygen indicators was reported by Morlotti \& Kuhnt (1992). This taxon is also known to live in areas where strong bottom-water currents occur, often the result of continental margin upwelling, which may cause reduced-oxygen bottom water (Linke \& Lutze, 1993).

It is clear from the distribution of inferred living forms that reworking by wave action or other processes (such as bioturbation, turbidity currents or scarring) of the Bass Canyon assemblages has not occurred, since the total faunal assemblage data (i.e., total living + recently dead + relict forms) is similar to the distribution of the live forms in the shallower biofacies (Fig. 11). Production rates were also estimated between species using the method described by Murray (1991) and used by Smith et al. (2001). There were no differential production rates greater than 10 or 12 times between species, suggesting that postmortem influences have not affected the biocoenosis.
Live foraminifera are however absent below the reducedoxygen zone. This may be due to the difficulty in distinguishing 'live' Rhabdammina spp. due to their agglutinated tests, constructed from planktonic foraminifera or it may be due to instability below the OMZ. Jorissen's 1988 study on the vertical distribution of living benthic foraminifera in submarine canyons off New Jersey, concludes that the relative lack of live faunas within submarine canyons is a result of the inherent instability of the environment, with small-scale mass wasting and/or scouring unfavourable for a stable ecosystem. Jorissen (1988) also states that straight canyon environments are more susceptible to ecosystem instability than meandering canyons.

As summarised in Fig. 11, the distribution of relict foraminifera in the Bass Canyon samples is confined mainly to shallow shelf samples (shallower than $145 \mathrm{~m}$ water depth). With the exception of Gaudryina convexa and Gaudryina quadrangularis, most recorded relict foraminiferal taxa in the Gippsland Basin are commonly found living at depths of less than $242 \mathrm{~m}$. In 
Recent foraminifera from Gippsland Basin, Australia

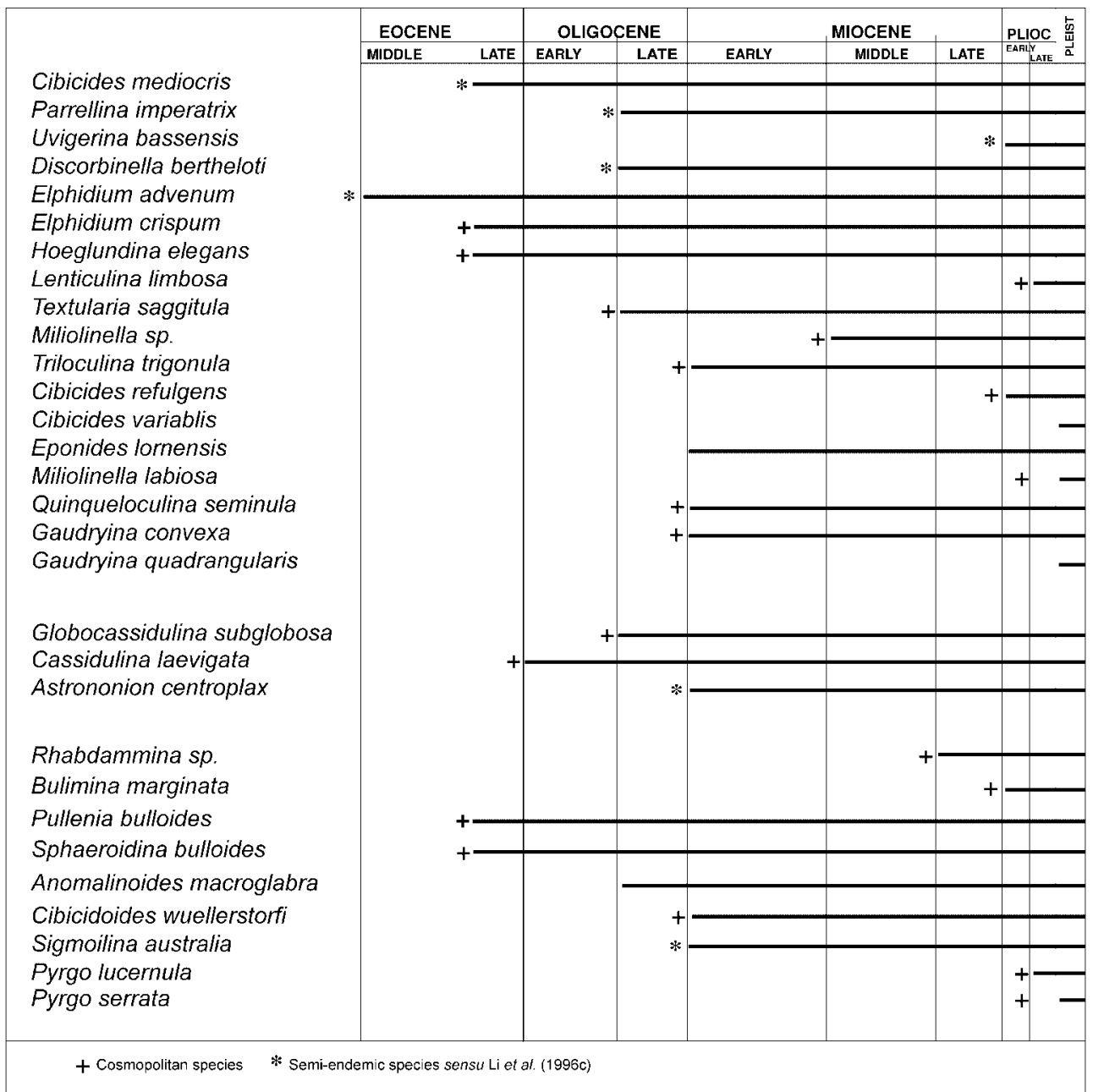

Fig. 12. The Cenozoic biostratigraphic ranges of the Bass Canyon benthic foraminifera listed in Fig. 11. The ranges for the taxa are for the Gippsland, Otway and Tasmanian Cenozoic strata, based on data from Parr (1945), Li et al. (1996c), Li \& McGowran (1997), Gallagher et al. (1999), Gallagher \& Holdgate (1996, 2000) and Holdgate \& Gallagher (1997). The biogeographic data were obtained from Li et al. (1996c) and Murray (1991).

Smith et al. (2001), it is suggested that only samples from less than $150 \mathrm{~m}$ water depth will contain in situ relict forms, as it is inferred that these relict forms may be a product of the last glacial maximum ( 19,000 years ago; Bard et al., 1990), during which time the sea level was between 120 and $150 \mathrm{~m}$ below present day (Chappell \& Shackleton, 1986).

\section{CENOZOIC PALAEOENVIRONMENTAL SIGNIFICANCE OF THE BASS CANYON FORAMINIFERAL FAUNAS}

Figure 12 summarizes the biostratigraphic ranges of 30 Bass Canyon foraminiferal taxa (listed in Fig. 11), based on stratigraphical studies of the Cenozoic successions of southeast Australia (northern Tasmania, the Otway Basin and the Gippsland Basin). In addition, cosmopolitan and (semi)endemic foraminifera are distinguished. The term (semi)endemic here refers to Bass Canyon foraminiferal taxa that are either confined to southern Australia, New Zealand, southwest Pacific or South America (sensu Li et al., 1996c).
The majority of the modern Bass Canyon fauna listed are cosmopolitan species, and show similar depth distributions to those listed in Murray (1991). These taxa are therefore useful for global palaeoenvironmental studies. The few (semi-)endemic taxa, suitable only for regional palaeo-environmental studies, are mostly restricted to the shelf. This is not surprising, as it is suggested in Smith et al. (2001) that modern deeper-living forms are more conservative since they evolved in relatively lowerstress eutrophic environments, than their shallower oligotrophic environment dwelling contemporaries.

\section{CONCLUSIONS}

- The neritic realm of the Bass Canyon ( $88 \mathrm{~m}$ to $300 \mathrm{~m}$ ) contains between 50 to $80 \% \mathrm{CaCO}_{3}$, with the maximum occurring on the western side of the canyon, due to the dominance of bryozoa in the carbonate 'factory'. Gravel-size sediments account for between 0 to $50 \%$ of the sediments, increasing with depth, with the maximum occurring on the western side of the canyon in the carbonate 'factory'. 
Sand-size sediments account for between 40 to $90 \%$ of the sediments, with mud-size sediments increasing with depth from less than $5 \%$ at $80 \mathrm{~m}$ to $30 \%$ at $\sim 200 \mathrm{~m}$ water depth. Cibicides mediocris, Parrellina imperatrix, Uvigerina bassensis, Cibicides cf. perforatus, Discorbinella bertheloti, Elphidium advenum, E. crispum and Quinqueloculina are the dominant taxa.

- The upper to middle bathyal realm of the Bass canyon contains facies with 60 to $90 \% \mathrm{CaCO}_{3}$, with the lowest values occurring at the head of the canyon, which may be related to the downslope transport of terrestrial/shelfal material. Gravel-size sediments account for between 0 to $60 \%$, reaching a maximum on the western side of the canyon. Sand-size sediments account for 40 to $90 \%$ and mud-size sediment account for 0 to $30 \%$ of the sediments. Dominant benthic taxa in the upper to middle bathyal realm of the Bass Canyon include Parrellina imperatrix, Rosalina and Uvigerina in the shallower samples, and Astrononion centroplax, Cibicides mediocris, Heterolepa elegans, Lenticulina and Globocassidulina subglobossa in the deeper samples. The percentage of planktonic foraminifera increase with depth from 68 to $96 \%$ dominated by Globorotalia inflata, with lesser amounts of Globigerina bulloides, Globorotalia hirsuta, Globorotalia truncatulinoides, Globigerinoides ruber, Orbulina universa and Globorotalia crassula.

- The lower bathyal zone in the Bass Canyon, incorporating the oxygen minimum zone, contains between 30 to $90 \%$ $\mathrm{CaCO}_{3}$, decreasing with depth due to the depth of the CCD. Percentages of gravel- and sand-size sediments decrease with depth due to the increase of mud, which accounts for over $50 \%$ of the sediments in the deeper $(>2000 \mathrm{~m})$ samples. Benthic foraminifera account for between 8 to $19 \%$ of the fauna in the middle to lower slope realm of the Bass Canyon, including Cibicidoides wuellerstorfi, Sphaeroidina bulloides, Bulimina marginata, Gyroidinoides spp., Pyrgo lucernula, Pyrgo serrata Rhabdammina agglutissima, and Reophax spp. Planktonic foraminifera in this realm include: Globorotalia inflata, Globigerina bulloides, Globorotalia hirsuta, Globorotalia truncatulinoides, Globigerinoides ruber, Orbulina universa, Globoquadrina dutertrei, Globorotalia scitula, Hastigerina siphonifera and Globorotalia crassula.

- The CCD is the region is estimated to occur at around $3600 \mathrm{~m}$, this is reflected by a decrease in percentage carbonate after this depth.

- Correspondence Analysis of the 61 parameters (percentage abundance of foraminifera and carbonate) in 36 samples yielded a clear depth-related pattern, although it is suggested that other related parameters such as dissolved oxygen and substrate also control the distribution of foraminifera.

- Relict foraminifera are restricted to shelfal depths, shallower than $145 \mathrm{~m}$. This pattern is similar to other shelf regions in Australia, where shelf areas were exposed during the Last Glacial Maximum, reworking shelf facies shallower than $150 \mathrm{~m}$.

- The distribution of living foraminifera is similar to the distribution of the total assemblage, suggesting that the surficial sediment is this region has not been significantly mixed by wave, slump or bioturbation processes.
- The majority of the modern Bass Canyon fauna listed are cosmopolitan species, with few (semi-)endemic taxa mostly restricted to the shelf, providing further evidence that modern deeper-living forms are more conservative since they evolved in relatively lower-stress eutrophic environments, than their shallower oligotrophic environment dwelling contemporaries.

\section{ACKNOWLEDGEMENTS}

This study was supported by a grant from the Australian Research Council. The authors thank David Taylor for providing the additional 'SPB' and 'Kimbla' samples, and the crew of the R/V Franklin for their help with collecting the Gippsland Basin samples during September to October, 1998. The authors thank two reviewers for their valuable assistance.

\section{APPENDIX 1: MARGALEF DIVERSITY INDEX}

$\mathrm{D}=\mathrm{S}-1 / \log \mathrm{N}$

$\mathrm{D}=$ Diversity

$\mathrm{S}=$ Number of species

$\mathrm{N}=$ Number of specimens

This coefficient more accurately relates each sample to one another as some samples have a different number of specimens picked than others (from Brenchley \& Harper, 1998).

\section{APPENDIX 2: SYSTEMATIC DESCRIPTIONS}

What follows is an evaluation of the key foraminiferal species discussed in this study.

\section{SUPRAGENERIC CLASSIFICATION Class Sarcodina}

Order Foraminiferida Eichwald, 1830

Suborder Miliolina Délage \& Herouard, 1896

Family Hauerinidae Schwager, 1876

Genus Miliolinella Wiesner, 1931

Type species. Vermiculum subrotundum Montagu, 1803.

Miliolinella australis (Parr, 1932)

(P1. 1, figs 1-2)

Type species. Quinqueloculina australis Parr, 1932 (p. 7, pl. 1, fig. 8).

Diagnosis. Flat circular test. Medium size, up to $250 \mu \mathrm{m}$ in diameter. Imperforate, porcellaneous, calcareous walls. Aperture at end of last chamber.

Locality and horizon. Rare inner to middle shelf. Stratigraphic Range: Quaternary to Recent.

Genus Pyrgo Defrance, 1824

Pyrgo lucernula (Schwager, 1866)

(Pl. 1, fig. 3)

Type species. Biloculina lucernula Schwager, 1866 (p. 202, pl. 4, fig. 14).

Diagnosis. Oval imperforate, calcareous, porcellaneous test, medium size. Biloculine chamber arrangement, joined by prominent keel. Rounded aperture on short neck. 
Locality and horizon. Rare on the lower slope. Stratigraphic Range: Early Pliocene to Recent.

$$
\text { Pyrgo serrata (Bailey, 1862) }
$$$$
\text { (Pl. 1, fig. 4) }
$$

Type species. Biloculina serrata Bailey, 1861 (p. 350, pl. 8, fig. f). Diagnosis. Oval imperforate, calcareous, porcellaneous test, medium size. Biloculine chamber arrangement, joined by prominent serrated keel. Rounded aperture on short neck.

Locality and horizon. Rare on the lower continental slope. Stratigraphic Range: Late Miocene to Recent.

Genus Quinqueloculina d'Orbigny, 1826

Quinqueloculina lamarckiana d'Orbigny, 1839

(P1. 1, figs 5-7)

Type species. Quinqueloculina larmarckiana 1839 (p. 189, pl. 11, figs 14-15).

Diagnosis. Quinqueloculine chamber arrangement with a sharp periphery, medium to large size (up to $400 \mu \mathrm{m}$ from aperture to base). Walls calcareous, imperforate and porcellaneous. Aperture is a large opening with bifid tooth.

Locality and horizon. Common in the inner shelf. Stratigraphic Range: Early Miocene to Recent.

\section{Suborder Textulariina Délage \& Herouard, 1896 \\ Family Rhabdamminidae Brady, 1884 \\ Genus Rhabdammina M. Sars, 1869}

Rhabdammina agglutissima Hofker, 1972 (in Brill, 1972)

(P1. 1, figs 8-9)

Type species. Rhabdammina agglutissima Hofker, 1972 (p. 28, pl. 5, figs 7-9).

Diagnosis. In the specimens illustrated, this taxon has an elongate, tubular test made of cemented planktonic foraminifera.

Locality and horizon. Rare to common from the middle to lower slope. Stratigraphic Range: Recent.

Family Hormosinidae Haeckel, 1894

Genus Reophax de Montfort, 1808

Reophax scorpiurus de Montfort, 1808

(Pl. 1, fig. 10)

Type species. Reophax scorpiurus Montfort, 180 (p. 331, fig. 130).

Diagnosis. Elongate test with chambers gradually increasing in size. Large size. Coarsely arenaceous walls.

Locality and horizon. Rare in the outer shelf. Stratigraphic Range: Recent.

Family Textulariidae Ehrenberg, 1838

Genus Textularia Defrance, 1824

Textularia saggitula Defrance, 1824

(Pl. 1, figs 11-12)

Type species. Textularia saggitula Defrance, 1824 (p. 344, pl. 13, fig. 5a,b).

Diagnosis. Small compressed agglutinated test with acute periphery. Low broad chambers with slightly depressed sutures.
Aperture is a crescent-shaped slit on the inner lip of the final chamber.

Locality and horizon. Common in the inner to middle shelf, rare in the outer shelf. Stratigraphic Range: Late Oligocene to Recent.

Suborder Rotalliina Délage \& Herouard, 1896

Family Elphidiidae Galloway, 1933

Genus Elphidium de Montfort, 1808

Elphidium advenum (Cushman, 1922)

(Pl. 1, figs 13-15)

Type species. Polystomella advena Cushman, 1922 (p. 56, pl. 9, figs 11-12).

Diagnosis. Planispiral bioconvex test. Smooth circular outline. Small to medium size. Umbilical region is perforated. Involute, with up to 15 chambers visible. Chambers separated by depressed sutures. Calcareous walled. The aperture is a row of pores at the base of the aperture face.

Locality and horizon. Shelf: Common in the Gippsland Lakes, dominant in the inner shelf, rare from middle to outer shelf. Stratigraphic Range: Eocene to Recent.

$$
\begin{gathered}
\text { Elphidium crispum (Linne, 1758) } \\
\text { (P1. 1, figs 16-17) }
\end{gathered}
$$

Type species. Nautilus crispum Linne, 1758 (p. 709).

Diagnosis. Planispiral, rounded, bioconvex test. Involute with up to 25 chambers visible. Slightly depressed curved sutures. Umbilical region covered with rounded perforated bosses. Calcareous walled. The aperture is a row of pores at the base of the aperture face.

Locality and horizon. Dominant on the middle shelf. Stratigraphic Range: Late Oligocene to Recent.

\section{Genus Parrellina Thalmann, 1951}

Parrellina imperatrix (Brady, 1881)

(P1. 1, figs 19-21)

Type species. Polystomella imperatrix Brady, 1881 (p. 66).

Diagnosis. Bilaterally symmetrical, involute, planispiral flatterned test. Medium to very large in size. Distinct sigmoidal sutures. Up to 20 chambers in final whorl, increasing in size. Megalospheric form contains up to 5 spines protruding from the sub-rounded periphery. Microspheric form may not have spines.

Locality and horizon. Rare to common across the shelf, increasing abundance with depth. Stratigraphic Range: Late Oligocene to Recent.

Family Discorbinellidae Sigal, 1952 Genus Discorbinella Cushman \& Martin, 1935

Discorbinella bertheloti (d'Orbigny, 1839)

(P1. 1, figs 22-24)

Type species. Rosalina bertheloti d'Orbigny, 1839 (in BakerWebb \& Berthelot, 1839) (p. 134, pl. 1, figs 28-30).

Diagnosis. Compressed, planoconvex test. Circular in outline. Ventral side is flat and evolute, with up to 10 chambers. Dorsal 
side is convex and involute. Curved sutures. Walls are hyaline, calcareous and finely perforated.

Locality and horizon. Rare to common across the shelf. Stratigraphic Range: Late Oligocene to Recent.

Family Uvigerinidae Haeckel, 1894

Genus Uvigerina d'Orbigny, 1826

Uvigerina bassensis Parr, 1950

(P1. 1, figs 26-28)

Type species. Uvigerina bassensis Parr, 1950 (p. 340, pl. 12, figs 19-20).

Diagnosis. Elongate, subfusiform, triserial test. Small to medium size. Later chambers become more inflated. Calcareous wall with longitudinal costae which are not continuous from one chamber to another. The rounded aperture is at the end of a short neck.

Locality and horizon. Common to dominant from the middle to outer shelf, common on the upper slope, rare on the middle slope. Stratigraphic Range: Pliocene to Recent.

Family Cibicididae Cushman, 1927

Genus Cibicides de Montfort, 1808

Cibicides mediocris Finlay, 1940

(Pl. 1, figs 29-31)

Type species. Cibicides mediocris Finlay, 1940 (p. 464, pl. 67, figs 198-199).

Diagnosis. Planoconvex, trochospiral test. Small to medium size. Slightly keeled with slowly enlarging chambers in the final whorl. Dorsal side is flattened, evolute and coarsely perforate, with strongly limbate sutures. Ventral side is smooth, involute. Slit-like aperture at base of final chamber.

Locality and horizon. Dominant across the shelf, extending down to the middle Slope. Stratigraphic Range: Late Eocene to Recent.

Cibicides refulgens de Montfort, 1808

(P1. 1, figs 18, 25, 32)

Type species. Cibicides refulgens de Montfort, 1808 (p. 122, fig. 123).

Diagnosis. Planoconvex test. Medium to large size. Rounded outline, pyramiddleal in lateral view. Dorsal side is flattened and coarsely perforated. Ventral side shows up to 6 chambers in final whorl, depressed sutures, perforate. Walls calcareous.

Locality and horizon. Rare on the inner to middle shelf. Stratigraphic Range: Pliocene to Recent.

Family Parrelloididae Hofker, 1956

Genus Cibicidoides Thalmann, 1939

Cibicidoides wuellerstorfi (Schwager, 1866)

(P1. 1, figs 33-34)

Type species. Anomalina wuellerstorfi Schwager, 1866 (p. 258, pl. 7, figs 105, 107).

Diagnosis. Low trochospiral test. Circular in outline. Medium size. Dorsal side flattened coarsely porous. Ventral side slightly convex with curved sutured. Final whorl contains up to 10 chambers, slowly enlarging with final chamber inflated. Walls calcareous and perforate.

Locality and horizon. Rare on the lower slope. Stratigraphic Range: Miocene to Recent

Family Vaginulinidae, Reuss, 1860

Subfamily Lenticulinae Chapman, Parr and Collins, 1934 Genus Lenticulina Lamarck, 1804

Lenticulina limbosa (Reuss, 1863)

(P1. 1, figs 35-37)

Type species. Cristellaria (Robulina) limbosa Reuss, 1863. (p. 55, pl. 6, fig. 69a,b).

Diagnosis. Lenticular, planispiral, bioconvex, involute test. Medium to very large size. Outline sub-rounded, sharp periphery with narrow keel. Sutures radiate from the large boss in the umbilical area below the Recent. Walls calcareous, hyaline.

Locality and horizon. Rare from the middle shelf to upper slope. Stratigraphic Range: Late Pliocene to Recent.

Family Nonionidae Schultze, 1854

Genus Astrononion Cushman \& Edwards, 1937

Astrononion centroplax Carter, 1958

(P1. 2, figs 1-3)

Type species. Astrononion centroplax Carter, 1958 (p.61, pl. 9, figs 95-97).

Diagnosis. Planispiral, involute, compressed, up to 10 chambers in final whorl. Small to medium size. Rounded periphery. Calcareous perforated walls. Tear-shaped depressions lay between the depressed umbilici and the periphery.

Locality and horizon. Rare to common from the middle to outer shelf. Stratigraphic Range: Miocene to Recent.

Family Cassidulinidae d'Orbigny, 1839

Genus Globocassidulina Voloshinova, 1960

Globocassidulina subglobossa (Brady, 1881)

(P1. 2, figs 4-6)

Type species. Cassidulina subglobossa Brady, 1881 (p. 430, pl. 54, fig. 17).

Diagnosis. Globose, sub-rounded test. Small to medium size. Slightly depressed sutures give plate like appearance of Recent. Rounded aperture toward base of final chamber. Walls calcareous and perforate.

Locality and horizon. Rare to common from the outer shelf to middle slope. Stratigraphic Range: Late Oligocene to Recent.

Family Buliminidae Jones, 1875

Genus Bulimina d'Orbigny, 1826

Bulimina marginata d'Orbigny, 1826

(Pl. 2, fig. 7)

Type species. Bulimina marginata d'Orbigny, 1826 (p. 269, pl. 12, figs 10-12).

Diagnosis. Elongate triserial test. Small to medium size. Later chambers slightly inflated, early chambers compressed and 
covered with spines. Aperture is a wide slit at the base of the last chamber. Wall calcareous.

Locality and horizon. Rare from the middle shelf to lower slope. Stratigraphic Range: Pliocene to Recent.

Family Sphaeroidinidae Cushman, 1927

Sphaeroidina bulloides d'Orbigny, 1826

(P1. 2, figs 8-9)

Type species. Sphaeroidina bulloides d'Orbigny, 1826 (p. 267, fig. 65).

Diagnosis. Subglobular, test. Medium size. Rounded periphery. Three chambers in last whorl. Crescent-shaped aperture at base of final chamber. Perforated calcareous wall.

Locality and horizon. Rare lower slope. Stratigraphic Range: Late Eocene to Recent.

Family Epistominidae Wedekind, 1937 Genus Hoeglundina Brotzen, 1948

Hoeglundina elegans (d'Orbigny, 1826) (Pl. 2, figs 10-12)

Type species. Rotalia (Turbinulina) elegans d'Orbigny, 1826 (p. 699, pl. 105, figs 4-6).

Diagnosis. Trochospiral, bioconvex test. Rounded outline. Medium size. Up to 10 chambers in the last whorl, with curved sutures, all of which is shown under the surface when the specimen in wet. Smooth calcareous hyaline walls.

Locality and horizon. Common to rare from the outer shelf to middle slope. Stratigraphic Range: Late Eocene to Recent.

Family Globorotalidae Cushman, 1927

Genus Globorotalia Cushman, 1927

Globorotalia inflata (d'Orbigny, 1839)

(Pl. 2, figs 13-15)

Type species. Globigerina inflata d'Orbigny, 1839 (in BarkerWebb \& Berthelot, 1839) (p. 134, pl. 2, figs 7-9).

Diagnosis. Globose to subtriangular test in axial orientation. Medium size. Rounded periphery. Three to 4 chambers in last whorl. Spiral side of final chamber is generally symmetrical with a flat base. Calcareous walls covered in pustules, becoming more prominent around the aperture. Aperture is a high elongated arch, often with a lip.

Locality and horizon. Dominant from outer shelf to lower slope in the Gippsland region. Stratigraphic Range: Pliocene to Recent.

Globorotalia truncatulinoides (d'Orbigny, 1839)

$$
\text { (P1. 2, figs 16-18, 22-23) }
$$

Type species. Rotalina truncatulinoides d'Orbigny, 1839 (in Barker-Webb \& Berthelot, 1839) (p. 132, pl. 2, figs 25-27).

Diagnosis. Strongly ventroconical test in axial orientation. Medium to large size. Rounded outline in spiral view. Angular periphery with keel. Up to 5 chambers in last whorl. Can be sinistrally or dextral coiled (as shown in Plate 2 figs 17, 22). Radial, slightly depressed sutures. Encrusted, porous, calcareous wall with few pustules. Slit like, lipped aperture at the base of the final chamber.

Locality and horizon. Occurs as up to $4 \%$ of the entire assemblage in the Gippsland Basin. Deep dwelling taxon. Stratigraphic Range: Pleistocene to Recent.

Globorotalia hirsuta (d'Orbigny, 1839)

(P1. 2, figs 19-21)

Type species. Rotalina hirsuta d'Orbigny, 1839 (in Barker-Webb \& Berthelot, 1839) (p. 131, pl. 1, figs 34-36).

Diagnosis. Bioconvex to spiroconical test in axial orientation. Medium size. Elliptical outline. Depressed umbilical face, conical spiral face. Weak keel at periphery. Four chambers in last whorl. Inside of last chamber on the spiral side shows a deeply concave trailing section with no elevation. Sutures are weakly curved in the direction of coiling. Small pustules cover the calcareous walls. Slit-like aperture at base of last chamber.

Locality and horizon. Recent: Occurs as up to $2 \%$ of the entire assemblage in the Gippsland region. Stratigraphic Range: Pleistocene to Recent.

Family Globigerinidae Carpenter, Parker \& Jones, 1862 Genus Orbulina d'Orbigny, 1839

Orbulina universa d'Orbigny, 1839

(P1. 2, fig. 24)

Type species. Orbulina universa d'Orbigny, 1839 (p. 2, pl. 1, fig. 1).

Diagnosis. Spherical test. Medium to large size. One chamber in final whorl. Calcareous perforated walls.

Locality and horizon. Recent: Common at all depths. Stratigraphic Range: Middle Miocene to Recent.

Genus Globigerina d'Orbigny, 1826

Globigerina bulloides d'Orbigny, 1826

(P1. 2, figs 25-27)

Type species. Globigerina bulloides d'Orbigny, 1826 (p. 277, models 17, 76).

Diagnosis. Globose, trochospiral test. Small to medium size. Four chambers in last whorl. Chambers inflated, increasing in size. Spiral side has earlier whorls. Large, open aperture in umbilical region. Calcareous, finely perforate, spinose wall.

Locality and horizon. Common to dominant in the outer shelf to lower slope in Gippsland. Prefers upwelling environments. Stratigraphic Range: Early Miocene to Recent.

\section{Manuscript received 17 December 2001 Manuscript accepted 10 March 2003}

\section{REFERENCES}

Albani, A.D. 1968. Recent foraminiferida from Port Hacking, New South Wales. Contributions from the Cushman Foundation for Foraminiferal Research, 19: 85-119.

Apthorpe, M. 1980. Foraminiferal distribution in the estuarine Gippsland Lakes system Victoria. Proceedings of the Royal Society of Victoria, 91: 207-233.

Bard, E., Hamelin, B. \& Fairbanks, R. 1990. U-Th ages obtained by mass spectrometry in corals from Barbados: sea level during the past 130,000 years. Nature, 346: 456-458. 
Bernhard, J.M. 1986. Characteristic assemblages and morphologies of benthic foraminifera from anoxic, organic-rich deposits. Jurassic through Holocene. Journal of Foraminiferal Research, 16: 207-215.

Brenchley, P.J. \& Harper, D.A.T. 1998. Palaeoecology, Ecosystems, Environments and Evolution. Chapman \& Hall, London, 1-402.

Cann, J.H. \& Gostin, V.A. 1985. Coastal sedimentary facies and foraminiferal biofacies of the St Kilda Formation at Port Gawler South Australia. Transactions of the Royal Society of South Australia, 109: 121-142.

Cann, J.H., Belperio, A.P., Gostin, V.A. \& Murray-Wallace, C.V. 1988. Sea-level history, 45,000 to 30,000 yr B.P., inferred from benthic foraminifera, Gulf St. Vincent South Australia. Quaternary Research, 29: $153-175$.

Carver, R.E. 1971. Procedures in Sedimentary Petrology. WileyInterscience, New York, 1-672.

Chappell, J. \& Shackleton, N.J. 1986. Oxygen isotopes and sea level. Nature, 324: 137-140.

Collins, A.C. 1953. Pleistocene foraminifera from Port Fairy Western Victoria. Memoirs of the National Museum of Victoria, 18: 93-105.

Collins, A.C. 1973. Port Phillip survey, 1957-1963 Foraminiferida. Memoirs of the National Museum of Victoria, 35: 1-62.

Davies, P.J. 1979. Marine geology of the continental shelf off southeast Australia. Bureau of Mineral Resources Bulletin (BMR), 195: $1-51$.

Gallagher, S.J. 1997. The use of multivariate statistics to determine the paleoenvironmental distribution of Lower Carboniferous foraminifera from Ireland. In: Ross, C.A., Ross, J.R.P. \& Brenckle, P.L. (Eds), Late Paleozoic Foraminifera; their Biostratigraphy, Evolution, and Paleoecology; and the Mid-Carboniferous Boundary. Special Publication of the Cushman Foundation for Foraminiferal Research, 36, 41-46.

Gallagher, S.J. \& Holdgate, G.R. 1996. Sequence stratigraphy and biostratigraphy of the onshore Gippsland Basin, S.E Australia. Field Guide Series 11, Sydney. Australasian Sedimentologists Group, Geological Society of Australia, 1-70.

Gallagher, S.J. \& Holdgate, G. 2000. The palaeogeographic and palaeoenvironmental evolution of an Palaeogene mixed carbonatesiliciclastic cool-water succession in the Otway Basin Southeast Australia. Palaeogeography, Palaeoclimatology, Palaeoecology, 156 $19-50$.

Gallagher, S.J., Jonasson, K. \& Holdgate, G. 1999. Foraminiferal biofacies and palaeoenvironmental evolution of an Oligo-Miocene cool-water carbonate succession in the Otway Basin, southeast Australia. Journal of Micropalaeontology, 18: 143-168.

Gallagher, S.J., Smith, A.J., Jonasson, K., Wallace, M.W., Holdgate, G.R., Daniels, J. \& Taylor, D. 2001. The Miocene palaeoenvironmental and palaeoceanographic evolution of the Gippsland Basin, Southeast Australia a record of Southern Ocean change. Palaeogeography, Palaeoclimatology, Palaeoecology, 172: 53-80.

Godfrey, J.S., Jones, I.S.F., Maxwell, J.G.H. \& Scott, B.D. 1980. On the Winter Cascade from Bass Strait into the Tasman Sea. Australian Journal of Marine and Freshwater Research, 31: 275-286.

Hamon, B.V. 1965. The East Australian Current, 1960-1964. Deep-Sea Research, 12: 899-921.

Harris, P., Radke, B., Smith, A.J., Glen, K., Rollet, N., Exon, N. \& Passlow, V. 2000. Marine geological data collected during Southern Surveyor Voyage 01/00. Eastern Bass Strait and Great Australian Bight (AGSO Research Cruise No. 224), Canberra, Australian Geological Society Organisation, 1-83.

Hayward, B.W., Grenfell, H.R., Reid, C.M. \& Hayward, K.A. 1999. Recent New Zealand shallow-water benthic foraminifera. Taxonomy, ecological distribution, biogeography, and use in palaeoenvironmental assessment. Institute of Geological and Nuclear Sciences monograph 21. New Zealand Geological Survey Palaeontological Bulletin, 75: 258pp.

Hennebert, M. \& Lees, A. 1991. Environmental gradients in carbonate sediments and rocks detected by correspondence analysis: examples from the Recent of Norway and the Dinantian of southwest England. Sedimentology, 38: 623-642.

Holdgate, G. \& Gallagher, S. 1997. Microfossil paleoenvironments and sequence stratigraphy of Tertiary cool-water carbonates, onshore Gippsland Basin, southeastern Australia. In: James, N. \&
Clarke, J. (Eds), Cool Water Carbonates. Special Publication of the Society for Sedimentary Geology, 56, 205-220.

James, N.P. 1997. The cool-water carbonate depositional realm. In: James, N. \& Clarke, J. (Eds), Cool and Temperate Water Carbonates. Special Publication of the Society of Economic Palaeontologists and Mineralogists, Tulsa, 1-20.

James, N.P. \& Kendall, A.C. 1992. Introduction to carbonate and evaporite facies models. In: Walker, R.G. \& James, N.P. (Eds), Facies Models. Geological Association of Canada, St. Johns, 265-276.

James, N.P., Collins, L.B., Bone, Y. \& Hallock, P. 1999. Subtropical carbonates in a temperate realm. Modern sediments on the southwest Australian Shelf. Journal of Sedimentary Research, 69: 1297-1321.

Johnson, K.R. \& Albani, A.D. 1973. Biotopes of Recent benthic foraminifera in Pitt Water, Broken Bay, New South Wales (Australia). Palaeontology, 14: 265-267.

Jones, H.A. \& Davies, P.J. 1983. Superficial sediments of the Tasmanian continental shelf and past of Bass Strait. Bureau of Mineral Resources Bulletin (BMR)Bulletin, 218, Canberra: 1-25.

Jorissen, F.J. 1988. Benthic foraminifera from the Adriatic Sea. Principles of phenotypic variation. Utrecht Micropaleontological Bulletins, 37: 1-174.

Knauss, J.A. 1997. Introduction to Physical Oceanography. PrenticeHall, New Jersey, 1-309.

Lees, A. 1989. SedUTIL and AFCal Computer Packages, Belgium. Université de Louvain.

Levitus, S. 1982. Climatological Atlas of the World Oceans. National Oceanic and Atmospheric Administration (NOAA) Professorial Paper, 13, 1-176.

Li, Q., McGowran, B., James, N., Bone, Y. \& Cann, J. 1996. Mixed foraminiferal biofacies on the mesotrophic, mid-latitude Lacepede Shelf South Australia. Palaios, 11: 176-191.

Li, Q., McGowran, B., James, N.P. \& Bone, Y. 1996. Foraminiferal biofacies on the mid-latitude Lincoln Shelf, South Australia: Oceanographic and sedimentological implications. Marine Geology, 129: 3-4.

Li, Q., Quilty, P.G., Moss, G. \& McGowran, B. 1996. Southern Australia endemic and semi-endemic foraminifera: a preliminary report. Journal of Micropalaeontology, 15: 169-185.

Li, Q., James, N.P., Bone, Y. \& McGowran, B. 1999. Palaeoceanographic significance of recent foraminiferal biofacies on the southern shelf of Western Australia: a preliminary study. Palaeogeography, Palaeoclimatology, Palaeoecology, 147: 101-120.

Li, Q. \& McGowran, B. 1997. Miocene climate oscillation recorded in the Lakes Entrance oil shaft, southern Australia: benthic foraminiferal response on a mid-latitude margin. Micropaleontology, 43: 149-164.

Linke, P. \& Lutze, G.F. 1993. Microhabitat preferences of benthic foraminifera - a static concept or a dynamic adaptation to optimise food acquisition? Marine Micropaleontology, 20: 215-234.

Loeblich, A.R. \& Tappan, H. 1987. Foraminiferal Genera and their Classification, vols 1 \& 2, New York. Van Nostrand Reinhold, $1-1182$.

Martinez, J.I. 1994. Late Pleistocene palaeoceanography of the Tasman Sea. Implications for the dynamics of the warm pool in the western Pacific. Palaeogeography, Palaeoclimatology, Palaeoecology, 112: 19-62.

Melguen, M. 1974. Facies analysis by "correspondence analysis". Numerous advantages of this new statistical technique. Marine Geology, 17: $165-182$.

Morlotti, E. \& Kuhnt, W. 1992. Agglutinated deep-water foraminifera of the Eocene Monte Piano Formation (Northern Apennines, Italy). Journal of Foraminiferal Research, 22: 214-228.

Murray, J.W. 1991. Ecology and Palaeoecology of Benthic Foraminifera. Longman Scientific and Technical, London, 1-397.

Parr, W.J. 1945. Recent foraminifera from Barwon Heads, Victoria. Proceedings of the Royal Society of Victoria, 56: 189-199.

Pflum, C.E., Frerich, W.E. \& Sliter, W.V. 1976. Gulf of Mexico Deep-water Foraminifera. Special Publication of the Cushman Foundation for Foraminiferal Research, 14, 1-126.

Pickard, G.L. \& Emery, W.J. 1990. Descriptive Physical Oceanography. An Introduction 5th edn. Pergamon Press, Oxford, 1-320. 
Sen Gupta, B.K. \& Machain-Castillo, M.L. 1993. Benthic foraminifera in oxygen-poor habitats. Marine Micropaleontology, $\mathbf{2 0}$ : 183-201.

Smith, A.J., Gallagher, S.J., Wallace, M., Holdgate, G., Daniels, J. \& Keene, J. 2001. The Recent temperate foraminiferal biofacies of the Gippsland Shelf. An analogue for Neogene environmental analyses in southeastern Australia. Journal of Micropalaeontology, 20: 127-142.

Smith, G.C. 1982. A review of the Tertairy-Cretaceous tectonic history of the Gippsland Basin and its control on coal measure sedimentation. Australian Coal Geology, 4: 1-37.

Tomczak, M. 1985. The Bass Strait Cascade during winter 1981. Continental Shelf Research, 4: 255-278.

Tomczak, M. \& Godfrey, J.S. 1994. Regional Oceanography. An Introduction. Pergamon, London, 1-422.
Walton, W.R. 1952. Techniques for recognition of living foraminifera. Contributions from the Cushman Foundation for Foraminiferal Research, 3: 56-60.

Wass, R.E., Conolly, J.R. \& MacIntyre, R.J. 1970. Bryozoal carbonate sand continuous along southern Australia. Marine Geology, 9: 63-73.

Yassini, I. \& Jones, B.G. 1995. Foraminiferida and Ostracoda from Estuarine and Shelf Environments on the Southeastern Coast of Australia. The University of Wollongong Press, Wollongong, 1-484.

Zheng, S. \& Fu, Z. 1990. Faunal trends and assemblages of the northern South China Sea Agglutinated foraminifera. In: Hemleben, C., Kaminski, M.A., Kuhnt, W. \& Scott, D.B. (Eds), Proceedings of the NATO Advanced Study Institute on Paleoecology, Biostratigraphy, Paleoceanography and Taxonomy of Agglutinated Foraminifera, Boston. Reidel Publishing Company, 541-563. 